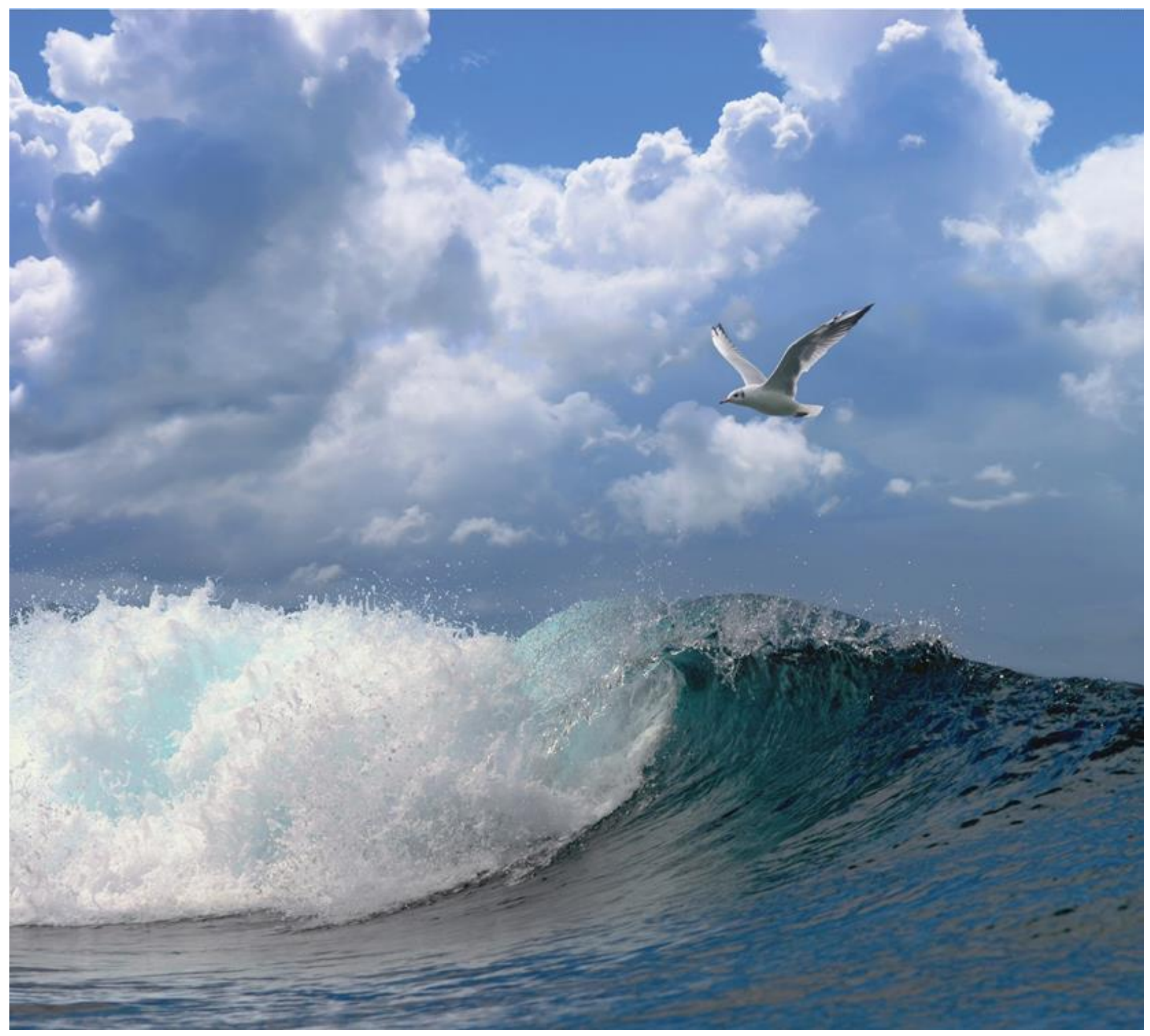

Cod-end selectivity for sole (Solea solea) and plaice (Pleuronectes platessa) in North Sea pulse-trawl fisheries

Best Practices II - WP4 selectivity 


\section{Cod-end selectivity for sole (Solea solea) and plaice (Pleuronectes platessa) in North Sea pulse-trawl fisheries}

Best Practices II - WP4 selectivity

Authors: Pieke Molenaar and Chun Chen

Publication date: 18 July 2018 
Cod-end selectivity for sole (Solea solea) and plaice (Pleuronectes platessa) in North Sea pulse-trawl fisheries, 2018. Best Practices II - WP4 selectivity Wageningen, Wageningen Marine Research (University \& Research centre), Wageningen Marine Research report C049/18. 30 pp.

Client: $\quad$ VisNed

Attn.: W. van Broekhoven

Postbus 59

8320 AB URK

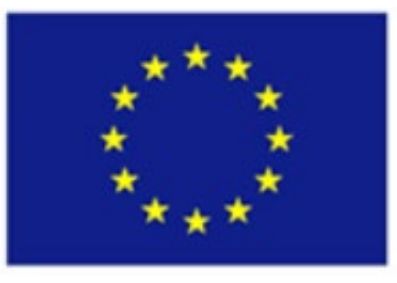

European Union, European Maritime and Fisheries Fund (EMFF)

This report can be downloaded for free from https://doi.org/10.18174/455754 Wageningen Marine Research provides no printed copies of reports

Wageningen Marine Research is ISO 9001:2008 certified.

(C) 2016 Wageningen Marine Research Wageningen UR

Wageningen Marine Research institute of Stichting Wageningen Research is registered in the Dutch traderecord nr. 09098104, BTW nr. NL 806511618
The Management of Wageningen Marine Research is not responsible for resulting damage, as well as for damage resulting from the application of results or related to the application of information found within its research. This report has been made on the request of the client and is wholly the client's property. This report may not be reproduced and/or published partially or in its entirety without the express written consent of the client. 


\section{Contents}

$\begin{array}{lr}\text { Summary } & 4\end{array}$

$1 \quad$ Introduction $\quad 5$

2 Research question $\quad 6$

$2.1 \quad$ Experimental design $\quad 6$

$3 \quad$ Materials and Methods $\quad 7$

$\begin{array}{lll}3.1 & \text { Experimental timing and locations } & 7\end{array}$

$\begin{array}{ll}3.2 \text { Gear } & 7\end{array}$

$\begin{array}{ll}3.3 & \text { Sampling procedure } \\ 3.4 & 10\end{array}$

3.4 Data analysis $\quad 11$

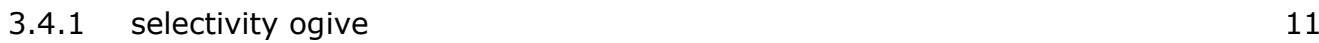

$4 \quad$ Results $r 12$

4.1 Catch composition $\quad 12$

4.1.1 Sole catches per experiment in weight $\quad 12$

4.1.2 Plaice catches per experiment in weight 13

$\begin{array}{lll}4.2 & \text { Length frequency distribution } & 14\end{array}$

4.2.1 Sole population distribution $\quad 14$

4.2.2 Plaice discards population distribution 15

$\begin{array}{lll}4.3 & \text { Selection curves } & 16\end{array}$

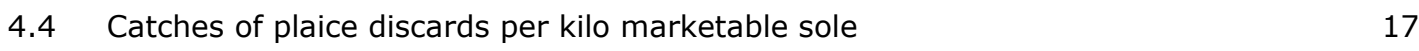

$\begin{array}{lll}4.5 & \text { Discussion } & 17\end{array}$

$5 \quad$ Conclusions and recommendations $r$

$\begin{array}{lr}\text { Acknowledgements } & \mathbf{2 0}\end{array}$

$\begin{array}{lr}\text { References } & 21\end{array}$

$\begin{array}{lr}\text { Justification } & 22\end{array}$

$6 \quad$ Annex sole length distribution and selectivity 23

$7 \quad$ Annex plaice length distribution and selectivity 25

$8 \quad$ Annex average catch weights per haul for other marketable species 28 


\section{Summary}

Electrified pulse trawls have replaced traditional tickler chain beam trawls in the North Sea fisheries for sole. This study investigates the mesh selection in pulse trawling of conventional cod-ends $(80 \mathrm{~mm}$ cod-end mesh) used in the current pulse trawl fishery, and the effects of increasing the cod-end mesh size to $90 \mathrm{~mm}$ on catches of sole (Solea solea) and undersized plaice (Pleuronectes platessa). Cod-end selectivity was estimated for $79-80 \mathrm{~mm}$ and $87-88 \mathrm{~mm}$ cod-ends during two experiments on a commercial pulse trawler using a cover cod-end. The results show that with a mesh size of 79-80 $\mathrm{mm}$ the length where $50 \%$ of the individuals are retained (L50) for sole is $19 \mathrm{~cm}$ with a selection range (SR) of $4.9 \mathrm{~cm}$. Given the observed length distribution of sole on the fishing ground this results in a $10 \%$ loss of marketable sole catches in the $24-27 \mathrm{~cm}$ length range. Increasing the mesh size in experiment one to $87 \mathrm{~mm}$ resulted in a L50 for sole of $22 \mathrm{~cm}$ with $\mathrm{SR}=4.9 \mathrm{~cm}$ and in experiment 2 to a L50 of $26 \mathrm{~cm}$ and SR $=4.9 \mathrm{~cm}$ was found for $88 \mathrm{~mm}$ cod-end, resulting in a loss of marketable sole of $24 \%$ and $38 \%$ in experiment 1 and 2 , respectively. These losses were detected in the $24-33 \mathrm{~cm}$ length range. Compared to sole, plaice showed steeper selection curve with a $L 50$ of $14.4 \mathrm{~cm}$ (SR 2.5) and $14.1 \mathrm{~cm}$ (SR 2.1) for the $79-80 \mathrm{~mm}$ cod-ends in experiment 1 and 2, respectively. In the $87 \mathrm{~mm}$ cod-ends, this L50 shifted to $15.6 \mathrm{~cm}$ (SR 2.5) for experiment 1 and $18.7 \mathrm{~cm}$ (SR 2.1) for the second experiment. The ratio of plaice discards per $\mathrm{kg}$ marketable sole caught was 0.4 in experiment one for $80 \mathrm{~mm}$ cod-ends, and increased to 0.5 in a $87 \mathrm{~mm}$ cod-end. In the second experiment this was 2.3 for $79 \mathrm{~mm}$ and 2.5 for $87 \mathrm{~mm}$. Increasing the minimum cod-end mesh to $90 \mathrm{~mm}$ thus increases the discard quantities of undersized plaice when the sole total allowable catch (TAC) is fully exploited. 


\section{Introduction}

In many countries, capture fisheries only land the marketable part of the catch and discard undersized or unwanted species. Discarding is particularly pronounced in bottom trawl fisheries. Discarding reduces the sustainable yield and may cause unwanted ecological consequences. FAO estimated global discards at 27 million tonnes in 1994 and 7.3 million tonnes in 2005 ((Alverson et al., 1994);(Kelleher, 2005)). In order to reduce discarding the EU has imposed an obligation to land all fish caught in the 2012 reform of the Common Fisheries Policy ((Borges, 2015)). It is expected that a ban on discarding will create an incentive for fishers to avoid fishing grounds with large number of discards or develop discard saving technologies ((Condie et al., 2013a; Condie et al., 2013b)). Discarding may be reduced by improving the selectivity of the gear. Gear modifications may comprise of release and separation panels, net configurations such as large meshed top panels, square mesh and other trawl modifications.

The North Sea flatfish fishery is one of the bottom trawl fisheries characterised by a large catch of undersized fish, due to the use of a $80 \mathrm{~mm}$ cod-end mesh required to catch the slender sole ((van Beek, 1998)). The fishery also deploys a number of tickler chains to chase sole out of the seabed which leads to unwanted impacts on the benthic ecosystem ((Jennings and Kaiser, 1998); (Kaiser and Spencer, 1996; Bergman and van Santbrink, 2000)).

In order to reduce the ecosystem impacts of the beam trawl fishery, electrified bottom trawls, pulse trawls, have been introduced in 2009. Since then, the number of Dutch beam trawl vessels that switched to using the pulse trawl has increased to 78 in 2018 (ICES, 2018). It is expected that the pulse stimulus may improve the gear selectivity as the response to the electrical stimulation will be size dependent (Stewart, 1975, 1977; (Soetaert et al., 2015)). Van Marlen et al (2014) reported the results of a comparative trawling trial with two pulse trawlers and one traditional beam trawler carried out shortly after the introduction of the innovative gear. The results showed that the catch efficiency of the pulse trawl was not statistically different from the traditional gear for sole. For the other species such as plaice and dab, however, the pulse trawl caught significantly less per area swept. In addition, the pulse trawl caught fewer undersized plaice and sole. A comparative trawling trial in 2015 suggested that the pulse trawl caught significantly more sole $(\mathrm{kg} / \mathrm{ha})$, both market-sized $(43 \%)$ and undersized $(61 \%)$, than the traditional tickler chain beam trawl. Plaice catches were equal. Compared with the experiment in 2011, when pulse fishing was just introduced, sole catch efficiency increased (van der Reijden et al., in prep). Both comparative studies showed a reduction in the catch of benthic invertebrates of around 50\%, in particular of infaunal species ((van Marlen et al., 2014); van der Reijden et al., submitted).

The differences in catch efficiencies estimated in the comparative trawling trials are the combined result of proportion of the fish in the trawl path that enter the net (available-selection sensu Millar and Fryer, 1999) and the proportion that is retained in the cod-end (contact-selection sensu Millar and Fryer, 1999). In the traditional gear, the tickler chains running at fixed distances in front of the ground-rope, prevent flatfish to escape underneath the ground-rope by digging into the sediment ((Creutzberg et al., 1987)). In the pulse trawl, the electrical stimulus invoke a cramp response, which disables the fish to respond to the gear. Once the fish is in the net and outside the electrical field, it recovers and return to its normal behaviour ((van Stralen, 2005); (de Haan et al., 2016)).

This study investigates the cod-end mesh selection of the trawl nets ( $80 \mathrm{~mm}$ cod-end mesh) used in the current pulse trawl fishery for flatfish in the North Sea, and study the effect of increasing the minimum cod-end mesh size to $90 \mathrm{~mm}$ on the catch of undersized sole (Solea Solea) and plaice (Pleuronectes platessa), and on the loss of marketable sized sole. 


\section{Research question}

This study addresses the effects of increasing the minimum cod-end mesh size in the Pulse trawl fishery for sole from the current $80 \mathrm{~mm}$ to $90 \mathrm{~mm}$ cod-ends. The main interests are the effects on the catch of marketable sole and unwanted catches of undersized plaice. For those species a minimum landing size (MLS) of $24 \mathrm{~cm}$ for sole and $27 \mathrm{~cm}$ for plaice is implemented. The selective performance is compared in terms of weights, length frequency for marketable and undersized catches, and selection curves for both species. The numbers and weight of fish caught are dependent on abundance on the trawled area and its size composition. This is less the case for the selective performance of the gear, in particular the cod-end selectivity is dependent on mesh opening and its specifics and the morphology of the target species.

\section{$2.1 \quad$ Experimental design}

During two 4.5-day experimental trips, parallel hauls with covered cod-ends were conducted on board of a commercial pulse trawler on the commercial fishing grounds in the southern North Sea. The trawler deployed two pulswing trouser trawls with two cod-ends for each trawl. Except for the cod-end covers this rigging is similar to the commercial practice. In the experiment, new experimental codends were used: two $80 \mathrm{~mm}$ cod-ends on starboard side and two $90 \mathrm{~mm}$ cod-ends on the portside trawl. To collect all individuals escaping through the meshes of each of the 80 and $90 \mathrm{~mm}$ experimental cod-ends (test), the covered cod-end method was used as described by Wileman et al., 1996. With this method a large small mesh cod-end is covering the cod-end to collect all fish that escape through the meshes of the cod-end. To account for potential catch efficiency differences between both trawls, halfway each experiment the portside cod-ends and accompanying cod-end covers were detached from the trawl and switched starboard, this was done the other way around for the starboard cod-ends and covers. For each sampled haul, weights of marketable commercial fishes as well as weights of undersized sole and plaice were recorded. Due to workload, length distribution of undersized plaice and undersized and marketable sole were measured only every second haul. 


\section{$3 \quad$ Materials and Methods}

\subsection{Experimental timing and locations}

The cod-end selectivity experiments were conducted from June 12-16 (week 24) and August 14-18 (week 33) 2017 on board a Dutch commercial pulse trawler in the Southern North Sea (ICES area IV) on regular fishing grounds of pulse trawlers characterized by sandy substrate and muddy banks (Figure 1). Fishing depth ranges between 17-42m during the first experiment and ranges between $20 \mathrm{~m}$ to $32 \mathrm{~m}$ during the second experiment. The vessels specifics can be found in Table 1 .

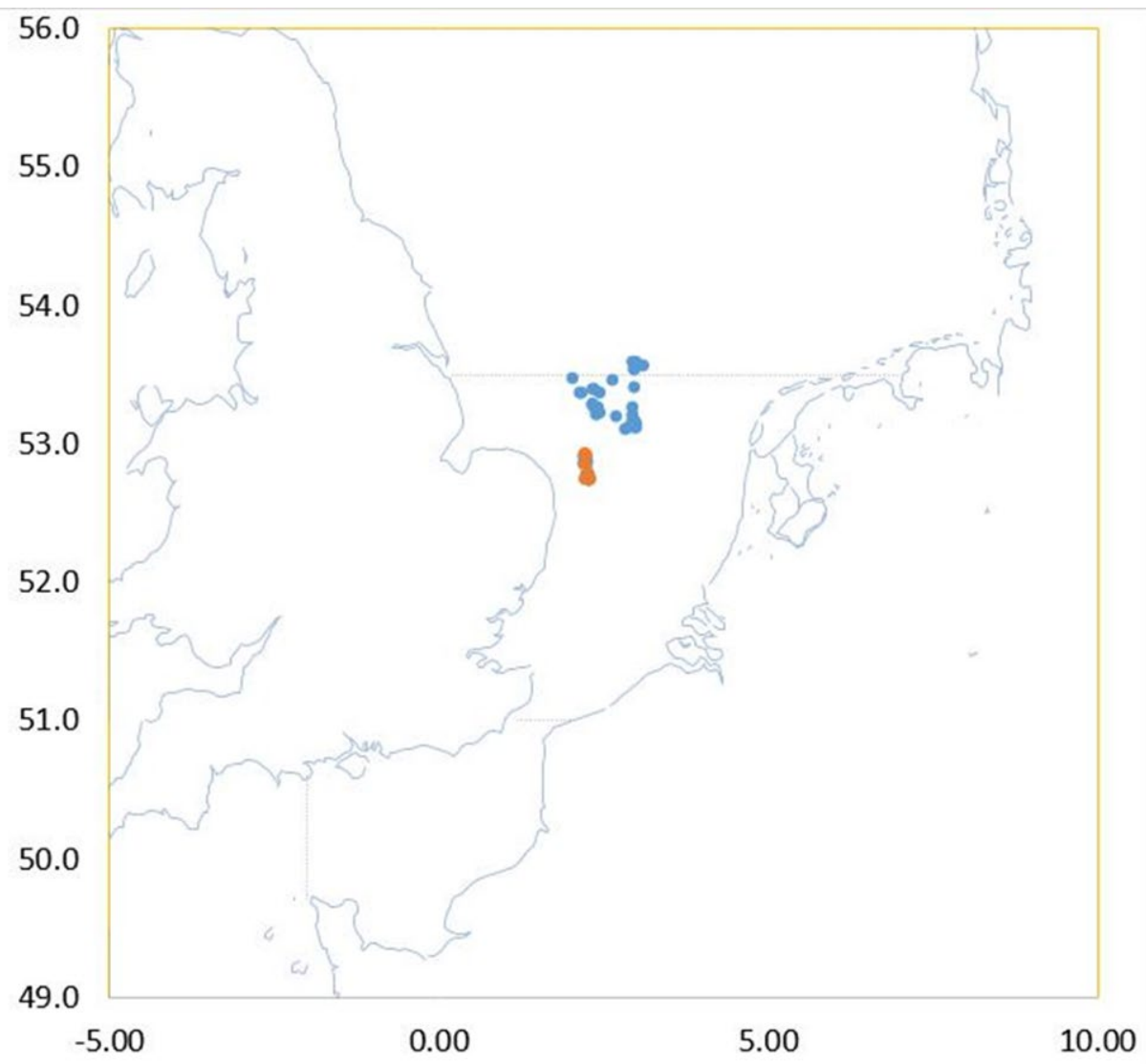

Figure 1. Sampled locations in the Southern North Sea for experiment 1 (orange) and experiment 2 (blue).

\subsection{Gear}

The commercial pulse trawls (pulswing) were used. Each pulse beam trawl consists of a $12 \mathrm{~m}$ wide wing type beam (HFK) with 28 electrodes and a trouser trawl with two cod-ends. This type of trawl is representative for six vessels of the Dutch pulse trawlers. Commercial towing speed (4.5 knots) and haul duration (120 minutes) was applied for all hauls. Trawl specifications including electrode design, electrics pulse characteristics, ground rope and net material can be found in Table 1 .

For the experiments four new 6.8 meter long cod-ends were constructed with a stretched cod-end mesh size of $80 \mathrm{~mm}$ and $90 \mathrm{~mm}$. Cod-end material, number of meshes and twine thickness is presented in Table 1. For the second experiment, the same cod-ends and covers were used except for the two $90 \mathrm{~mm}$ cod-ends. Two new $90 \mathrm{~mm}$ cod-ends were constructed according the same dimensions (Table 1). 
The cod-end cover length was limited to 1.5 times the cod-end length, due to the vessels limited operational lifting height capacity. Longer cover designs have handing difficulties on board of this type of beam trawler. All four experimental cod-ends were individually equipped by a single twine cod-end cover with $40 \mathrm{~mm}$ diamond (TO) mesh size (Table 1). In the covers upper panel an $2 \mathrm{~m}$ opening was constructed to enable catch handling of the cod-ends. Before starting a new haul this opening was sewed with an rope. To protect the covers bottom panel from damage related to bottom contact it was protected over its full length by piece of net equipped with dolly ropes.

Each cover was equipped with three rubber 'fishermen's' kites (Figure 4) and three egg shaped floats (buoyancy: $2.5 \mathrm{~kg}$ ) to ensure sufficient opening between cod-end and cover and minimize the risk of cod-end masking. Kites were constructed from $10 \mathrm{~mm}$ thick rubber mats $(50 \times 45 \mathrm{~cm})$ and were connected to the trawl with two $20 \mathrm{~cm}$ ropes in the rear aft and $40 \mathrm{~cm}$ ropes in the front aft. To ensure an upright position in the water an additional float tied on top of the front aft. Prior to the trails the effectivity of the kites and floats were visually inspected during two short hauls with GoPro camera's

Table 1. Specifics of vessel, gear and cod-ends used in the selectivity trails

\begin{tabular}{|c|c|c|}
\hline Specifics & & \\
\hline \multirow[t]{6}{*}{ Vessel } & Engine power (Kw) & 1119 \\
\hline & Tonnage (GT) & 424 \\
\hline & Length $(\mathrm{m})$ & 40 \\
\hline & Gear & Sumwing pulse \\
\hline & Number of gears & 2 \\
\hline & Fishing speed (kn) & 4.5 \\
\hline \multirow[t]{2}{*}{ Wing } & Width (m) & 12 \\
\hline & Length (m) & 1.1 \\
\hline \multirow[t]{3}{*}{ False ground rope } & Type & Rubber discs \\
\hline & Length (m) & 12 \\
\hline & Diameter (mm) & 250 \\
\hline \multirow[t]{5}{*}{ Electrodes } & Number & 28 \\
\hline & Type & HFK \\
\hline & $\begin{array}{l}\text { Total length including isolated } \\
\text { first section }(\mathrm{m})\end{array}$ & 7.6 \\
\hline & $\begin{array}{l}\text { Distance between electrodes } \\
(\mathrm{cm})\end{array}$ & 41.5 \\
\hline & $\begin{array}{l}\text { Length electrodes on seabed } \\
\text { (pulse field) }(\mathrm{m})\end{array}$ & 4.8 \\
\hline \multirow[t]{4}{*}{ Conductor elements } & Number & 10 \\
\hline & Diameter (mm) & 30 \\
\hline & Length (mm) & 125 \\
\hline & $\begin{array}{l}\text { Distance between elements } \\
(\mathrm{mm})\end{array}$ & 22 \\
\hline \multirow[t]{5}{*}{ Pulse } & Power per trawl (kW) & 7.2 \\
\hline & Width $(\mu s)$ & 260 \\
\hline & Frequency $(\mathrm{Hz})$ & 80 \\
\hline & $\begin{array}{l}\text { Peak voltage over electrode } \\
\text { (V) }\end{array}$ & $60 \mathrm{~V}$ \\
\hline & $\begin{array}{l}\text { Maximum exposure time to } \\
\text { pulse field (s) }\end{array}$ & 2.08 \\
\hline \multirow[t]{5}{*}{ Trawl } & Type & Trouser pulse trawl \\
\hline & Number of cod-ends per trawl & 2 \\
\hline & Total length (m) & 40 \\
\hline & Twine cod-end & PE double knotted twine \\
\hline & Twine thickness (mm) & 4 \\
\hline
\end{tabular}




\begin{tabular}{|l|l|l|}
\hline Specifics & \\
\hline Cod-end $(80 \mathrm{~mm})$ & Length (\# mesh) & 70 \\
\hline Cod-end $(90 \mathrm{~mm})$ & Round (\# mesh) & 88 \\
\hline & Length (\# mesh) & 64 \\
\hline Cover cod-end (40 mm) & Round (\# mesh) & 80 \\
\hline & Length (\# mesh) & 200 \\
\hline & Round (\# mesh) & 253 \\
\hline & Twine cover cod-end & PE single twine \\
\hline & Twine thickness (mm) & 3 \\
\hline & Number of kites & 3 \\
\hline & Number of floats & 3 \\
\hline
\end{tabular}
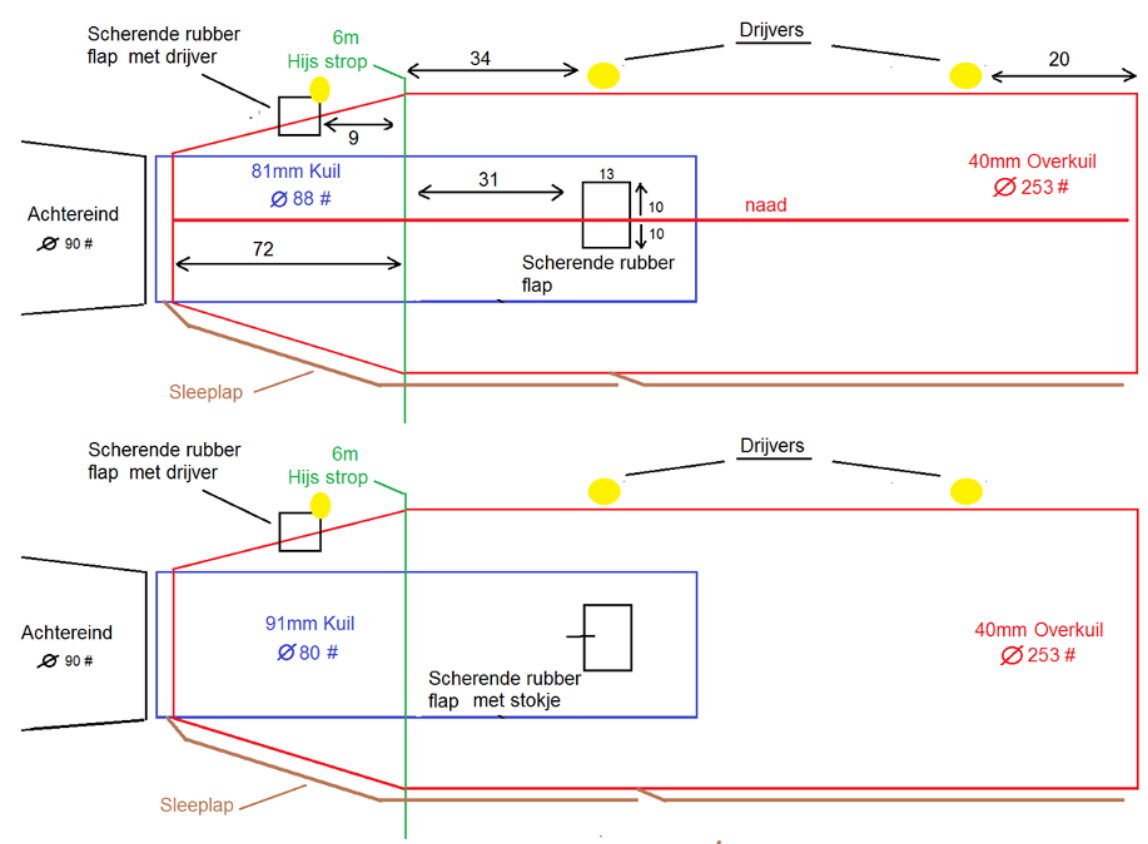

Figure 2. Schematic drawing of the cod-ends and covers including modifications (kites, floats) to prevent the cover masking the cod-ends meshes. Cod-end (blue) and cod-end cover (red) designs with floats (yellow) and kites (black squares), protection netting with dolly ropes (brown) and lifting rope (green).

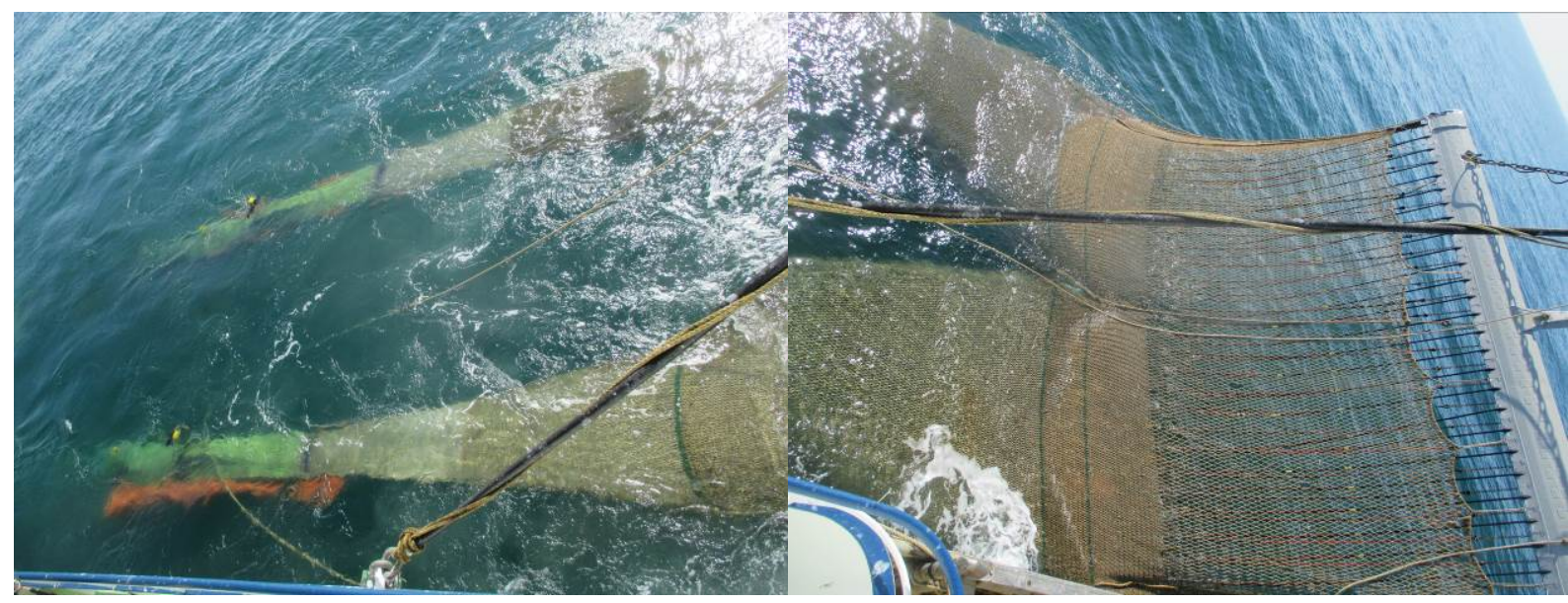

Figure 3. Left image shows the double cod-end of the port side trouser trawl with cod-end covers (green) and kites (black/yellow). Right image shows the Pulswing beam with electrodes. 


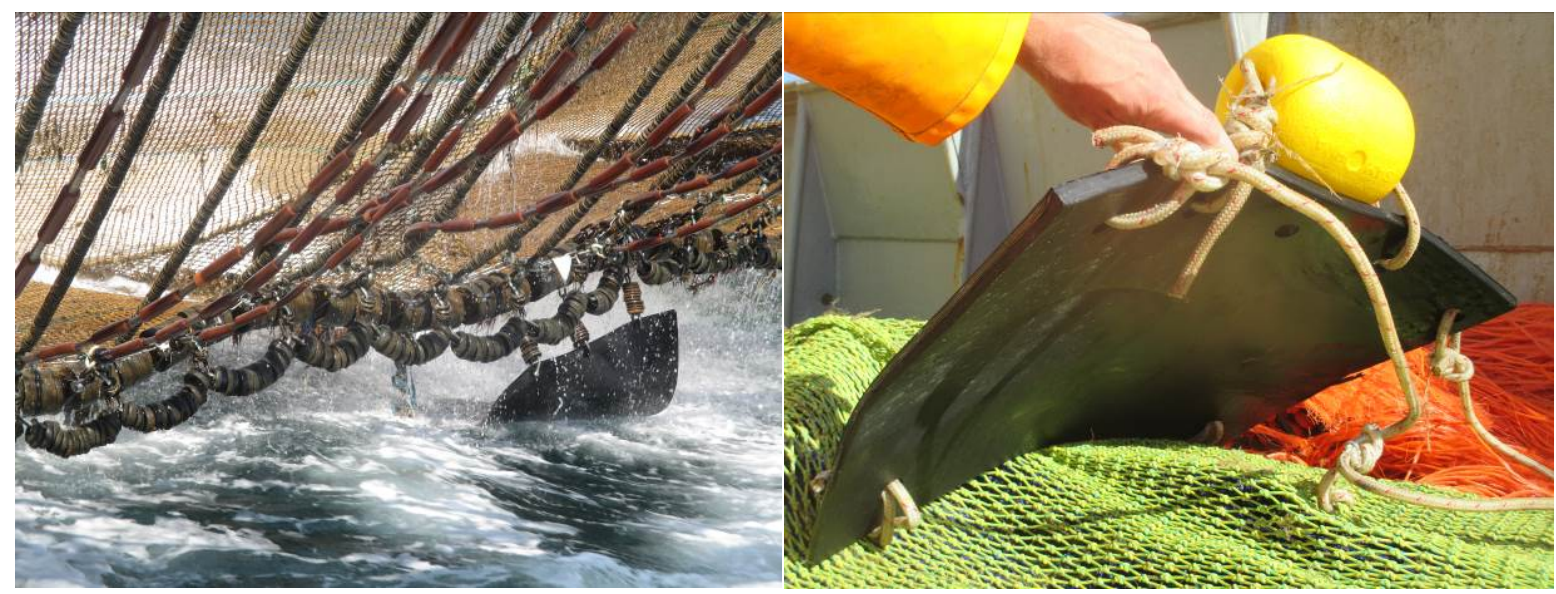

Figure 4. Ground rope the trawl (left) and a kite attached to the cover cod-end (right)

\subsection{Sampling procedure}

The first experiment 21 hauls were sampled for weight and of those 12 were sampled for length. The second experiment 25 hauls were sampled for weight and 14 for length (Table 2).

For each haul trawling position, duration, speed, depth were the trawl was deployed and sea state were recorded by the skipper on a trawl list. After hauling the trawls, the starboard and portside covered cod-ends were emptied in separate hoppers, the two $80 \mathrm{~mm}$ cover cod-ends were emptied in one hopper, where the both $90 \mathrm{~mm}$ cod-ends were emptied in the second hopper. After processing the catch from the covers the catch from the test cod-ends ( 80 and $90 \mathrm{~mm}$ ) were processed separately. The catch was processed on a conveyor belt, all marketable fish and every individual sole and plaice were collected from the catch and stored in baskets. Catches of cod-end and cover were marked with a colour code to avoid confusion. Sole was sorted in marketable and undersized individuals prior to weighing the fractions. For all species, catch weights of marketable fish were collected from both test $(80 \mathrm{~mm}, 90 \mathrm{~mm})$ and cover $(40 \mathrm{~mm})$ cod-ends. Catch weight per fraction and species was measured on a sea state compensated Marelec scale. For every second sampled haul length distribution (cmbelow) was determined for all sole (undersized and marketable sized) and undersized plaice. For each fraction, at least 300 fish were measured if available, in case of larger catch fractions a subsample was measured. During the second experiment (week 33) no subsampling was applied and all sole were measured for the length sampled hauls. The number of fish measured for each experiment are given in Table 2.

Table 2. Sampled hauls and hauls were sole and undersized plaice were measured.

\begin{tabular}{ccccc} 
Experiment & $\begin{array}{c}\text { Hauls sampled } \\
\text { (Weight) }\end{array}$ & $\begin{array}{c}\text { Hauls sampled } \\
\text { (length) }\end{array}$ & $\begin{array}{c}\text { \# Sole length } \\
\text { measured }\end{array}$ & $\begin{array}{c}\text { \# Plaice length } \\
\text { measured }(<27 \mathrm{~cm})\end{array}$ \\
\hline 1 & 21 & 12 & 13.842 & 5687 \\
\hline 2 & 25 & 14 & 6013 & 10.407 \\
\hline
\end{tabular}

Cod end mesh size was measured with an OMEGA Gauge (Fonteyne et al. 2007) at $125 \mathrm{~N}$ (cod-end mesh) and $50 \mathrm{~N}$ (cover) for 20 meshes in the longitudinal direction of the net of all cod-ends and covers. For both trails, the mesh size was measured after haul 4 and after the last haul, the average mesh size is each cod-end and cover is given in Table 3. 
Table 3. Average mesh size in $\mathrm{mm}$ (SD) for each cod-end and cover for experiment 1 and 2 . For each cod-end, 20 consecutive meshes were measured with an OMEGA gouge in after the $4^{\text {th }}$ haul and at the end of the trail.

\begin{tabular}{lllllllll} 
& Cod-end 1 & Cover 1 & Cod-end 2 & Cover 2 & Cod-end 3 & Cover 3 & Cod-end 4 & Cover 4 \\
Experiment1 & $\mathbf{7 9 . 7}(2.4)$ & $40.7(1.2)$ & $\mathbf{7 9 . 6}(1.6)$ & $41.1(1.7)$ & $\mathbf{8 7 . 3}(1.7)$ & $40.5(0.9)$ & $\mathbf{8 7 . 2}(2.0)$ & $40.5(1.1)$ \\
\hline Experiment2 & $\mathbf{7 8 . 8}(1.8)$ & $39.6(1.4)$ & $\mathbf{7 8 . 7}(2.0)$ & $39.5(1.0)$ & $\mathbf{8 7 . 4}(2.1)$ & $39.2(1.7)$ & $\mathbf{8 8 . 1}(2.1)$ & $39.3(1.6)$ \\
\hline
\end{tabular}

\subsection{Data analysis}

\subsection{1 selectivity ogive}

Collected data was digitized in Billie turf 8.0, checked for inconsistencies with SAS and analysed in R (R Development Core Team, 2004) and the R packages "Ime4" (Douglas Bates etc., 2015). A glmm with binomial distribution of the response variable and a logit link function was applied. The response variables were expressed as the presence/absence in the cod-end. Fish length, mesh size and experiment ID (with their interactions) were included as fixed effects, while the haul ID was included as a random intercept. Model coefficients were estimated through maximum likelihood. The best fitted model was selected using minimum AIC. 


\section{$4 \quad$ Results}

As presented in Table 3 measured mesh opening slightly deviated from $80 \mathrm{~mm}$ and $90 \mathrm{~mm}$ during both experiments. As mesh opening is important for the results, the average measured mesh opening for each experiment is used for describing and interpreting the results.

\subsection{Catch composition}

Catch weights of marketable turbot, brill, dab and red gurnard are presented in annex 8. forty-six hauls were included in the analysis for plaice and sole for marketable catches and discards. For experiment 1, 21 hauls were weight sampled including 12 hauls with length measurements. Experiment 2 included 25 hauls of which 14 with length measurements. Sole and plaice catch composition will be presented in average weights per haul for both landings and discards.

\subsubsection{Sole catches per experiment in weight}

Overall marketable sole catches (cod-end + cover) per trawl (cod-end plus cover) did not significantly differ between starboard and port-side nets for experiment 1 and 2 . In experiment 1 , on average 63 $\mathrm{kg}$ of marketable sole was caught per haul per trawl. Of the total marketable sole catch entering the trawl in the experiment, $89 \%$ was retained in the $80 \mathrm{~mm}$ cod-end while $76 \%$ was retained in the 87 $\mathrm{mm}$ cod-end. In experiment 2 the overall sole catches were lower, with a total of $29 \mathrm{~kg}$ for the $79 \mathrm{~mm}$ cod-end and cover and $32 \mathrm{~kg}$ for the $88 \mathrm{~mm}$ trawl. Of those catches $87 \%$ was retained in $79 \mathrm{~mm}$ and $62 \%$ in the $88 \mathrm{~mm}$ cod-end. Undersized sole catches were for both trawls on average $24 \mathrm{~kg}$ per haul for experiment 1, 55\% was retained in the $80 \mathrm{~mm}$ where $41 \%$ was retained in the $87 \mathrm{~mm}$. For experiment 2 this was $8.4 \mathrm{~kg}$ for the $79 \mathrm{~mm}$ cod-end and 9.8 for the $88 \mathrm{~mm}$, for those undersized fish $51 \%$ and $29 \%$ was retained (Table 4 \& Figure 6 ).

Table 4. Mean (SE) catch weight $(\mathrm{kg})$ of sole landings $(>24 \mathrm{~cm}$ ) and undersized discards per haul for tip 1 and 2 . Weights are given for cod-end and cover together, for the cod-end and cover separately and the weight percentage of the total weight that retained in the cod-end.

\begin{tabular}{|c|c|c|c|c|c|c|}
\hline Experiment & $\begin{array}{l}\text { Mesh size } \\
(\mathrm{mm})\end{array}$ & Size Class & $\begin{array}{l}\text { Total (Cod-end + } \\
\text { cover) }\end{array}$ & Cod-end & Cover & $\begin{array}{c}\text { Retained in cod-end } \\
\text { (\%) }\end{array}$ \\
\hline & & & Mean SE & Mean SE & Mean SE & Mean SE \\
\hline \multirow[t]{4}{*}{1} & 80 & landings & $62.8 \quad 5.9$ & $56.4 \quad 5.5$ & 6.40 .8 & $89.6 \quad 1.3$ \\
\hline & 80 & discards & 24.51 .6 & 13.40 .9 & 11.11 .0 & 55.02 .6 \\
\hline & 87 & landings & 63.24 .5 & 48.94 .1 & 14.31 .1 & $\begin{array}{ll}76.4 & 1.7\end{array}$ \\
\hline & 87 & discards & 24.01 .7 & 9.60 .6 & $14.4 \quad 1.4$ & $41.4 \quad 2.4$ \\
\hline \multirow[t]{4}{*}{2} & 79 & landings & 29.21 .9 & 25.61 .8 & 3.60 .4 & $\begin{array}{ll}87.1 & 1.3\end{array}$ \\
\hline & 79 & discards & 8.41 .1 & $\begin{array}{ll}4.4 & 0.7 \\
\end{array}$ & $4.0 \quad 0.5$ & $\begin{array}{lll}51.3 & 2.3\end{array}$ \\
\hline & 88 & landings & $\begin{array}{ll}31.6 & 1.8\end{array}$ & $\begin{array}{ll}19.7 & 1.3\end{array}$ & 11.90 .8 & 61.91 .6 \\
\hline & 88 & discards & 9.81 .0 & 2.90 .4 & $\begin{array}{ll}6.9 & 0.7\end{array}$ & 29.11 .9 \\
\hline
\end{tabular}




\begin{tabular}{lllrrr}
\hline tripID & SSE_CATEGORY & out_group & P_value & est_diff \\
\hline trip1 & d & cover & 0.0 & 3.3 \\
trip1 & l & cover & 0.0 & 7.8 \\
trip1 & d & test & 0.0 & -3.9 \\
trip1 & l & test & 0.0 & -7.5 \\
trip2 & d & cover & 0.0 & 2.9 \\
trip2 & l & cover & 0.0 & 8.4 \\
trip2 & d & test & 0.0 & -1.6 \\
trip2 & l & test & 0.0 & -5.9 \\
\hline
\end{tabular}

Figure 5. Paired t-test result comparing average weight per haul in $87-88 \mathrm{~mm}$ vs. $79-80 \mathrm{~mm}$ mesh sizes, for landing and discards respectively. The results shown that the average landing as well as discards weight of sole significantly $(p<0.05)$ differs between $87-88 \mathrm{~mm}$ and $79-80 \mathrm{~mm}$ mesh openings in both experiments.
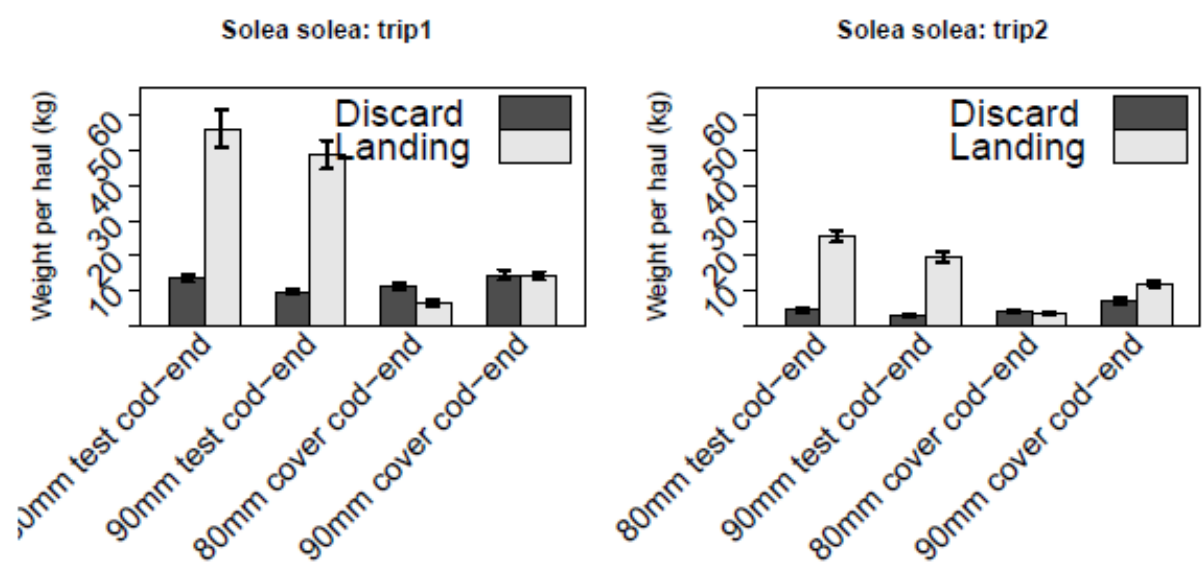

Figure 6 . Average catch weights $(\mathrm{kg})$ per haul for sole landings $(>24 \mathrm{~cm})$ and discards $(<24 \mathrm{~cm})$ in the $80 \mathrm{~mm}$ and $87 \mathrm{~mm}$ cod-ends and cover cod-ends for experiment 1 (left) and $79 \mathrm{~mm}$ and $88 \mathrm{~mm}$ cod-ends and cover cod-ends for experiment 2 (right).

\subsubsection{Plaice catches per experiment in weight}

For both experiments all marketable plaice $(>27 \mathrm{~cm})$ was found in the 79-80 and 87-88 mm cod-ends (Table 5). Overall undersized plaice catches (cod-end + cover) per trawl were different for experiment 1 and 2 , on average 24 and $28 \mathrm{~kg}$ of undersized plaice was caught in trawls during experiment 1, of those fish $91 \%$ was retained in the $80 \mathrm{~mm}$ cod-end and $87 \%$ in the $87 \mathrm{~mm}$ cod-end. In experiment 2 the overall plaice catches were higher. For the undersized plaice a total of $58 \mathrm{~kg}$ for the $79 \mathrm{~mm}$ codend and cover and $70 \mathrm{~kg}$ for the $88 \mathrm{~mm}$ cod-end. Of those catches $87 \%$ was retained in $79 \mathrm{~mm}$ and $62 \%$ in the $88 \mathrm{~mm}$ cod-end (Table 5 \& Figure 8 )

Table 5. Mean (SE) of the catch weight $(\mathrm{kg})$ of marketable plaice $(>27 \mathrm{~cm}$ ) and undersized discards per haul for tip 1 and 2 . Weights are given for cod-end and cover together, for the codend and cover separately and the weight percentage of the total weight retained in the cod-end.

\begin{tabular}{|c|c|c|c|c|c|c|}
\hline Experiment & $\begin{array}{l}\text { Mesh size } \\
(\mathrm{mm})\end{array}$ & Class & $\begin{array}{l}\text { Total (Cod-end + } \\
\text { cover) }\end{array}$ & Cod-end & Cover & $\begin{array}{l}\text { Retained in cod-end } \\
\qquad(\%)\end{array}$ \\
\hline & & & Mean SE & Mean SE & Mean SE & Mean SE \\
\hline \multirow[t]{4}{*}{1} & 80 & landings & $24.2 \quad 2.9$ & $24.2 \quad 2.9$ & 00 & 1000 \\
\hline & 80 & discards & 24.43 .2 & 22.03 .0 & 2.40 .6 & $90.6 \quad 2.2$ \\
\hline & 87 & landings & 24.03 .2 & 24.03 .2 & 00 & 1000 \\
\hline & 87 & discards & 28.04 .5 & $22.8 \quad 3.2$ & $5.2 \quad 2.1$ & 86.62 .5 \\
\hline \multirow[t]{3}{*}{2} & 79 & landings & 56.58 .9 & 56.58 .9 & 00 & 1000 \\
\hline & 79 & discards & 58.08 .5 & 51.98 .2 & 6.11 .0 & $\begin{array}{ll}86.6 & 2.3\end{array}$ \\
\hline & 88 & landings & 59.48 .5 & 59.48 .5 & 00 & 1000 \\
\hline
\end{tabular}




\begin{tabular}{lllrr}
\hline tripID & SSE_CATEGORY & out_group & P_value & est_diff \\
\hline trip1 & $\mathrm{d}$ & cover & 0.2 & 2.8 \\
trip1 & $\mathrm{d}$ & test & 0.6 & 0.8 \\
trip2 & $\mathrm{d}$ & cover & 0.0 & 17.4 \\
trip2 & $\mathrm{d}$ & test & 0.0 & -5.5 \\
trip1 & $\mathrm{l}$ & test & 0.9 & -0.2 \\
trip1 & $\mathrm{d}$ & cover & & 0.0 \\
trip2 & $\mathrm{l}$ & test & 0.6 & 2.9 \\
trip2 & $\mathrm{l}$ & cover & & 0.0 \\
\hline
\end{tabular}

Figure 7. Paired t-test result comparing average weight per haul in $87-88 \mathrm{~mm}$ vs. $79-80 \mathrm{~mm}$ mesh sizes, for landing and discards respectively. The results shown that the average discards weight of plaice significant $(p<0.05)$ differs between $87-88 \mathrm{~mm}$ and $79-80 \mathrm{~mm}$ mesh size opening only in experiment 2 .
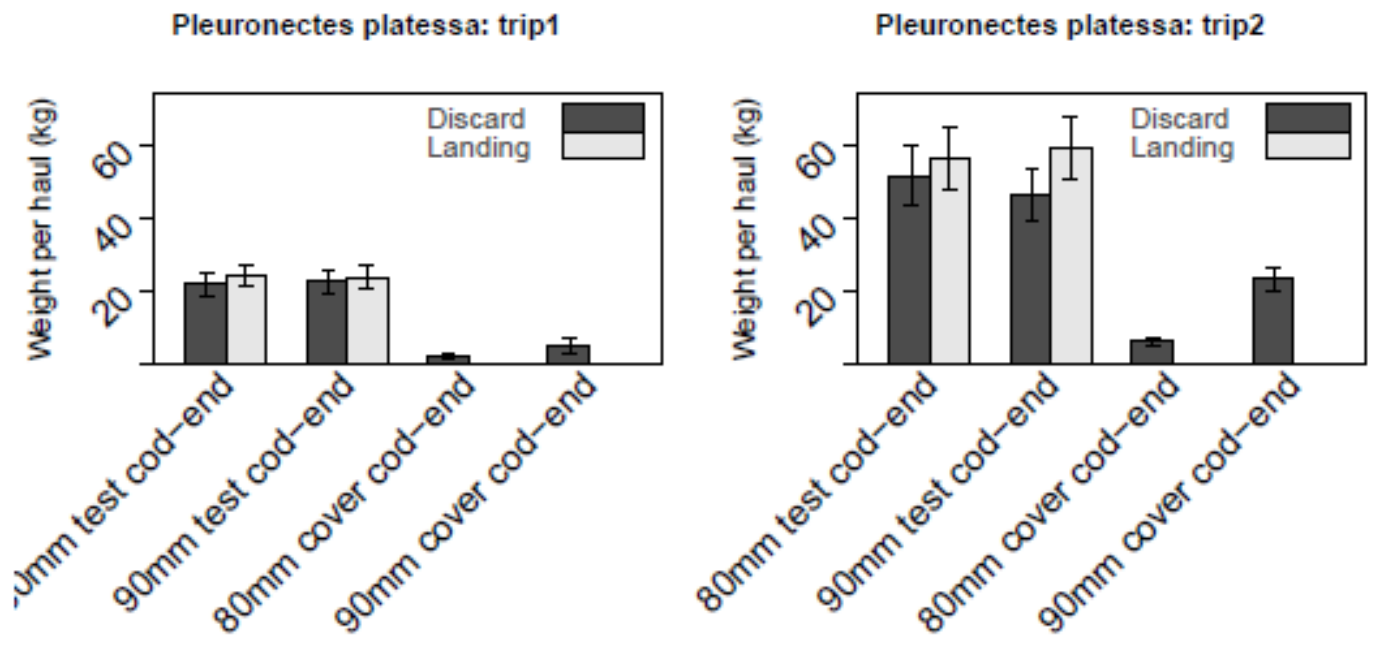

Figure 8 Average catch weights $(\mathrm{kg})$ per haul for marketable- and plaice discards $(<27 \mathrm{~cm})$ in the 87 $88 \mathrm{~mm}$ and 79-80 mm cod-ends and cover cod-ends for experiment 1 (left) and experiment 2 (right).

\subsection{Length frequency distribution}

Length of each individual fish in both cod-end and cover was measured for every second sampled haul, this enables to express the population length frequency (LF) distribution for each haul (annex 6 \& 7). Sampled hauls show a large variation in the LF distribution of the population for both species, therefore the population LF is given for all individuals of a certain species per experiment.

\subsubsection{Sole population distribution}

The LF distribution for all catch fractions (test cod-ends and covers) and the total available population for each trawl is given in Figure 9. The total available populations (black line) were not different for both trawls (dashed $87-88 \mathrm{~mm}$ and solid $79-80 \mathrm{~mm}$ ) during experiment 1 , this is also visible for experiment 2 for sole larger than $23 \mathrm{~cm}$ and smaller than $19 \mathrm{~cm}$, in between the numbers in the 88 $\mathrm{mm}$ trawl were higher. In experiment 1 only sole smaller than $27 \mathrm{~cm}$ escapes from the $80 \mathrm{~mm}$ codend, this increases towards $29 \mathrm{~cm}$ for the $87 \mathrm{~mm}$ cod-end. Similar pattern is visible for the $79 \mathrm{~mm}$ cod-end in experiment 2, although this is not present for the $88 \mathrm{~mm}$ cod-end. In this experiment sole up to $33 \mathrm{~cm}$ managed to escape through the $88 \mathrm{~mm}$ mesh openings. 
Solea solea: trip1

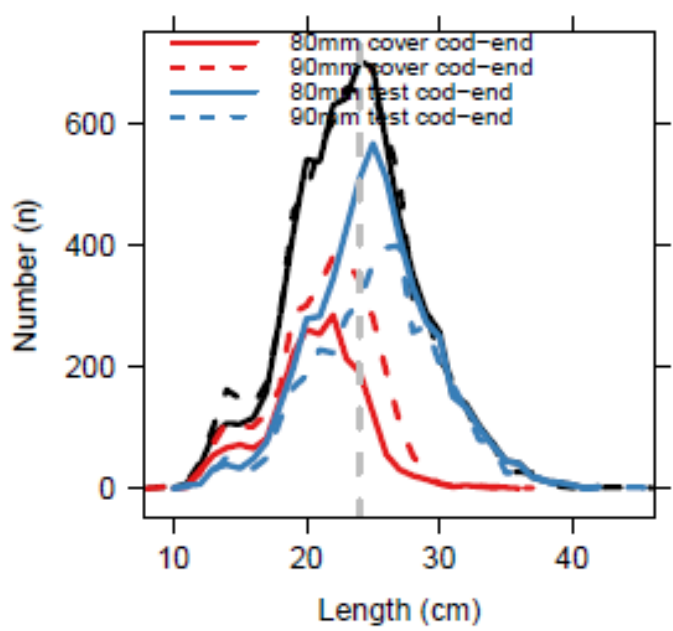

Solea solea: trip2

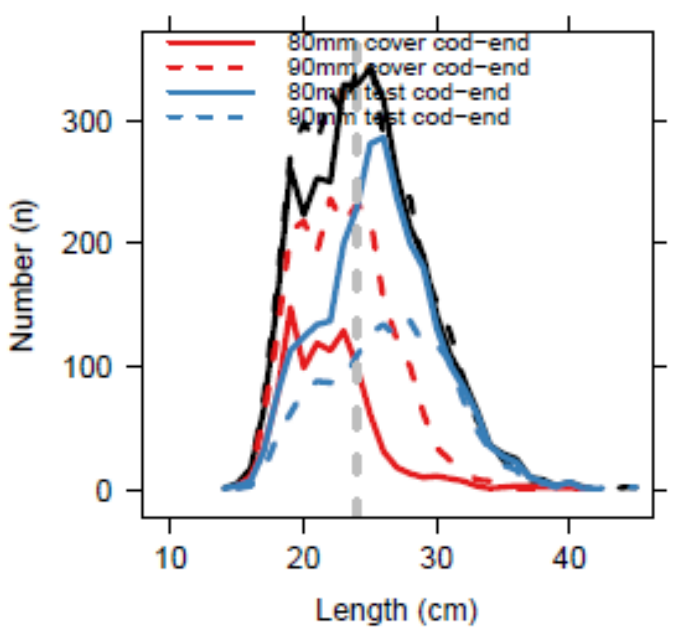

Figure 9. Sole length frequency per cod-end and covers caught for experiment 1 (left) and experiment 2 (right). The black lines indicates the population distribution of the cod-end (blue) and cover (red) together for 79-80 mm (solid line) and 87-88 $\mathrm{mm}$ (dashed line). The grey dashed line in the graph presents the minimum landing size $(24 \mathrm{~cm})$.

\subsubsection{Plaice discards population distribution}

The LF distribution for all undersized catch fractions (test cod-ends and covers) and the total available undersized population for each trawl is given in Figure 10. The total available populations (black line) were different for both trawls during experiment 1, Differences were mainly found in the $10-17 \mathrm{~cm}$ range with higher numbers in the $80 \mathrm{~mm}$ cod-end. For experiment 2 the available populations is comparable, with slightly higher numbers for $88 \mathrm{~mm}$ cod-end in the in the $19-23 \mathrm{~cm}$ range. In experiment 1 plaice smaller than $17 \mathrm{~cm}$ escapes from the $80 \mathrm{~mm}$ cod-end, this increases towards 20 $\mathrm{cm}$ for the $87 \mathrm{~mm}$ cod-end. For the $79 \mathrm{~mm}$ cod-end in experiment 2 a similar pattern is visible, where plaice smaller than $18 \mathrm{~cm}$ could escape. For the $88 \mathrm{~mm}$ cod-end in experiment 2, plaice smaller than $24 \mathrm{~cm}$ managed to escape through mesh openings.

Pleuronectes platessa: trip1

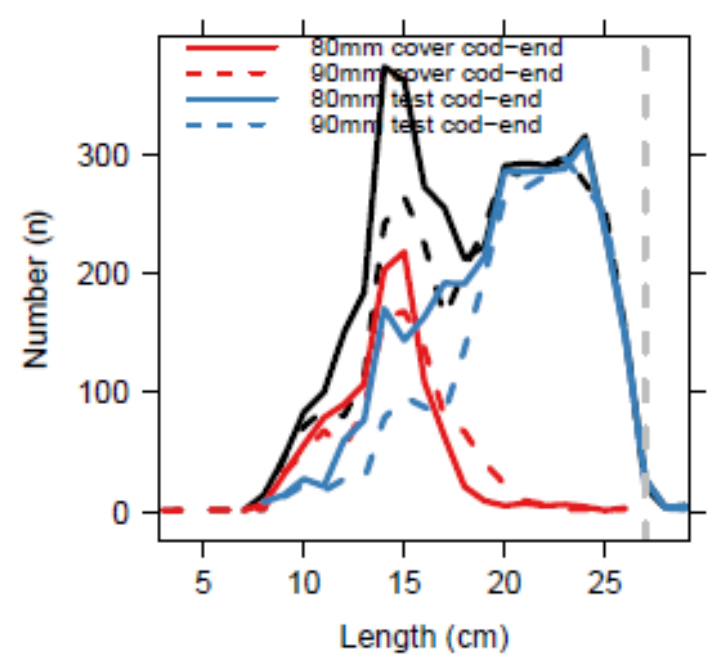

Pleuronectes platessa: trip2

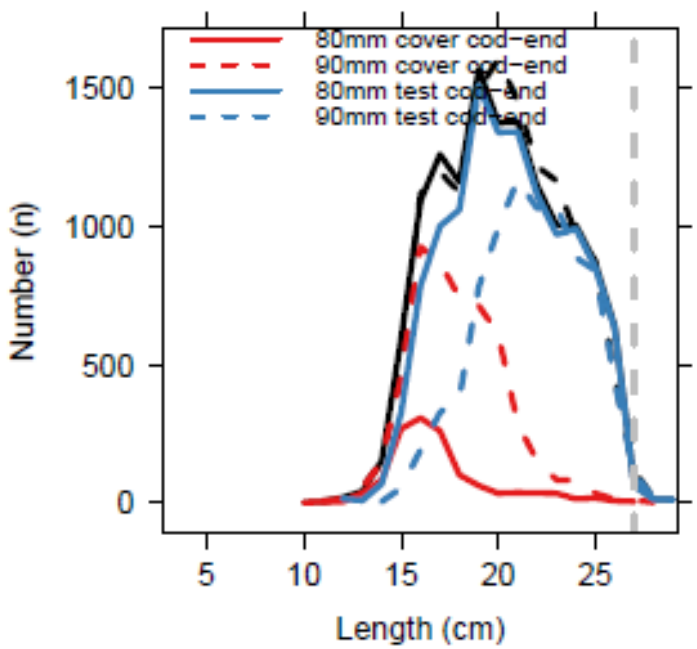

Figure 10. Plaice length frequency per cod-end and covers caught for experiment 1 (left) and experiment 2 (right). The black lines indicates the population distribution of the cod-end and cover together for 79-80 $\mathrm{mm}$ (solid line) and $87-88 \mathrm{~mm}$ (dashed line). The grey dashed line in the graph presents the minimum landing size $(27 \mathrm{~cm})$. 


\subsection{Selection curves}

Cod-end selectivity curves and parameters were estimated for sole and plaice, the probability of retaining an individual of a certain length in the cod-end is expressed by the selectivity curve and range. The selected model with the minimum AIC includes the interaction between experiment and treatment (79-80 $\mathrm{mm}$ vs. $87-88 \mathrm{~mm}$ ), implying that the mesh size effect differs between the two experiments. Different to sole, plaice has a different optimal model. The optimal model with the minimum AIC includes the interaction between experiment and treatment (79-80 mm vs. $87-88 \mathrm{~mm}$ ), as well as the interaction between experiment and length. This implies that not only the mesh size effect, but the length effect also differs between the two experiments. In experiment 2, the length effect is also getting stronger. Therefore, the estimated selectivity is presented for each experiment separately.

Sole yields a flatter selectivity curve as compared to plaice, with a length at $50 \%$ retention (L50) of 18.9 and $19.3 \mathrm{~cm}$ for experiment 1 and 2 for the $79-80 \mathrm{~mm}$ cod-ends (Table 6 \& Figure 11). No significant difference was detected for the $79-80 \mathrm{~mm}$ selectivity for both experiments (i.e. the optimal was without experiment interaction). In the $87 \mathrm{~mm}$ cod-end a $L 50$ of $22.2 \mathrm{~cm}$ was estimated for experiment 1 and $26.1 \mathrm{~cm}$ for the $88 \mathrm{~mm}$ cod-end in experiment 2 . The cod-end selectivity of the 79$80 \mathrm{~mm}$ and $87-88 \mathrm{~mm}$ was significantly different for both experiments.

Plaice showed steep selection curve with a L50 of 14.4 for the $80 \mathrm{~mm}$ and $14.1 \mathrm{~cm}$ for the $79 \mathrm{~mm}$ codends (Table 6 \& Figure 11) with no significant difference between experiments. In the $87 \mathrm{~mm}$ codends this L50 shifted to 15.6 for experiment 1 and $18.7 \mathrm{~cm}$ for the $88 \mathrm{~mm}$ cod-ends in experiment 2 . Although the larger undersized plaice $(<27 \mathrm{~cm})$ has a significantly higher chance of being retained in the $87-88 \mathrm{~mm}$ cod-end, for both mesh sizes a full cod-end retention for plaice is reached before the minimum landing size. Observed probabilities and estimated curves are per experiment and species are presented in annex $6 \& 7$.

Table 6. Estimated lengths at 50\% cod-end retention (L50) and selection range with $95 \%$ confidence intervals for sole and plaice for experiment 1 and 2. CI UL \& CI LL are Confidence Interval Upper limit and Lower Limit

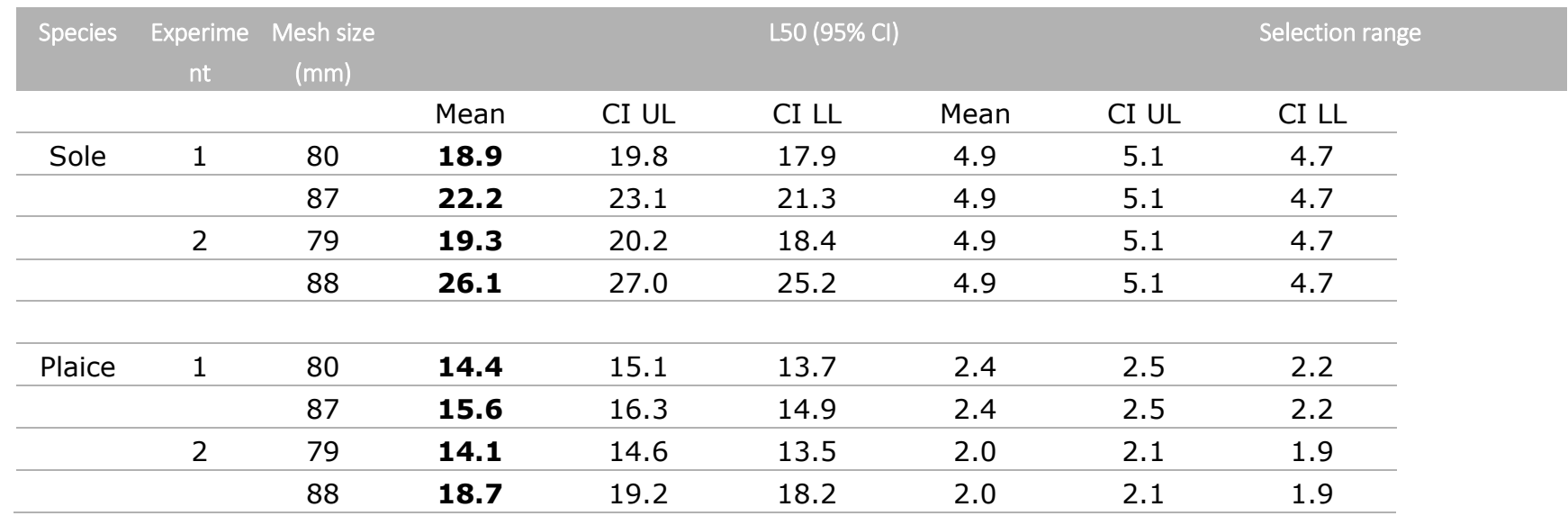



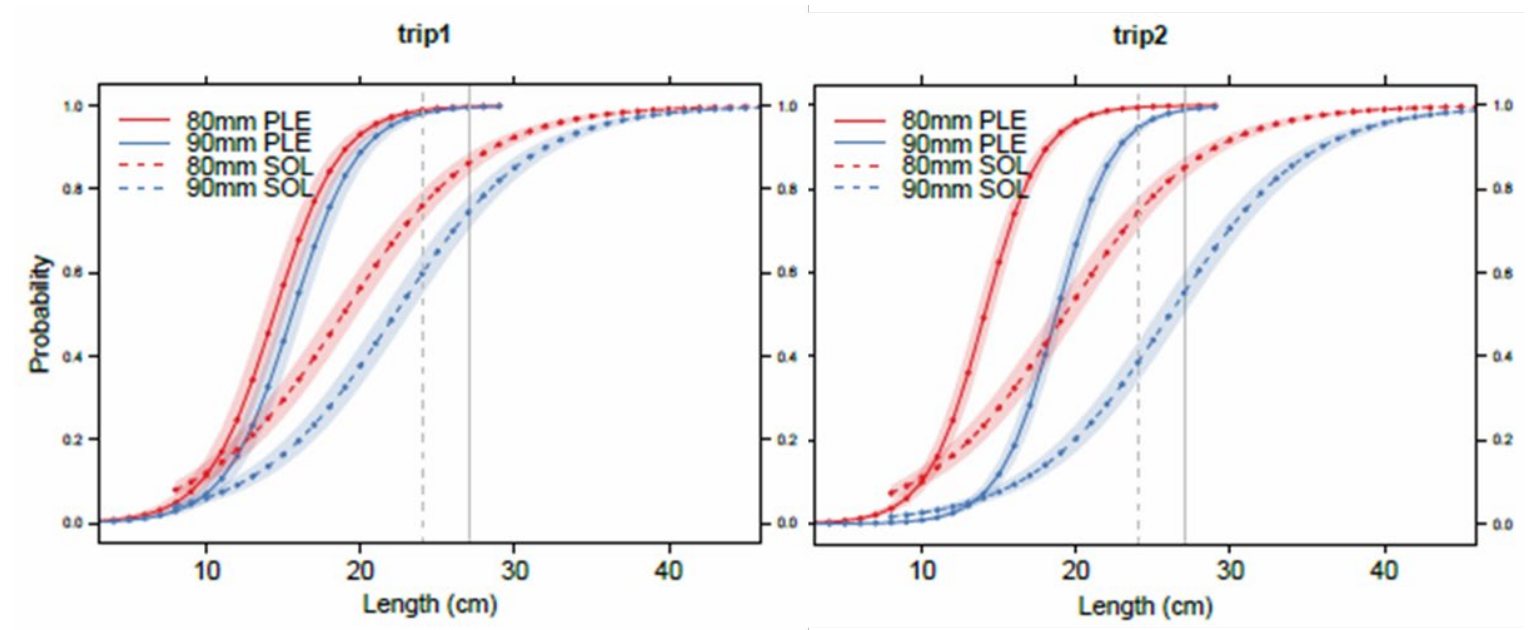

Figure 11. Estimated selectivity of $79-80$ and $87-88 \mathrm{~mm}$ cod-ends with $95 \%$ confidence interval for Sole (SOL) and plaice (PLE) for experiment 1 and 2 . The dashed grey line presents the minimum landing sized for sole $(24 \mathrm{~cm})$, the solid grey line the minimum landing size for plaice $(27 \mathrm{~cm})$.

\subsection{Catches of plaice discards per kilo marketable sole}

With recording the weight of the sole and plaice caches during both experiments the ratio of weight of undersized plaice per kilogram of marketable sole was calculated to assess the effectivity of reducing plaice bycatch by means of increasing the cod-end mesh size. The results are given in Table 7. During experiment 1 sole catches were good and there were limited catches of undersized plaice, this resulted in $0.4 \mathrm{~kg}$ undersized place per kilogram of marketable sole in the catches of the $80 \mathrm{~mm}$ cod-end. This ratio increased to 0.5 for the $87 \mathrm{~mm}$ cod-end. Sole catches were lower for experiment 2 while substantial amounts of undersized plaice were present. Subsequently the ratio went up to $2.3 \mathrm{~kg}$ undersized plaice per kilogram of marketable sole. For $88 \mathrm{~mm}$ cod-end this ratio was 2.5 during this experiment.

Table 7. Average weight ratio (SE) for catches of undersized plaice per $\mathrm{kg}$ marketable sole $(\mathrm{kg} / \mathrm{kg})$ for the 79-80 and 87-88 mm cod-ends for experiment 1 and 2.

\begin{tabular}{cccc} 
Experiment & Mesh size cod-end & $\begin{array}{c}\text { Ratio kg plaice discard per kg } \\
\text { marketable sole }\end{array}$ & SE \\
\hline 1 & 80 & 0.4 & 0.1 \\
\hline 2 & 87 & 0.5 & 0.1 \\
\hline & 79 & 2.3 & 0.4 \\
\hline & 88 & 2.5 & 0.4 \\
\hline
\end{tabular}

\subsection{Discussion}

This study assesses the effect of increasing the minimum cod-end mesh size in the sole fishery from $80 \mathrm{~mm}$ towards $90 \mathrm{~mm}$, the effects were primarily focussed on marketable sole and undersized plaice. The revenues of vessels in this $80 \mathrm{~mm}$ pulse trawl fishery primarily rely on valuable sole catches, and a reduction in the catch of this target species will reduce the revenue and the economic profitability and income for the skipper and crew. The weight of the marketable plaice may be equal or higher than the sole, but due to their lower market value their contribution to the revenue is lower. The strong, slim and flexible morphological body characterises of sole result in a relative flat selection curve where 
even a proportion of the larger marketable fish may escape from the $80 \mathrm{~mm}$ cod-ends. Even with a 79 $\mathrm{mm}$ cod-ends, as used in the experiments, this flat selection curve with an $L 50$ of $19 \mathrm{~cm}$ resulted in a $10-13 \%$ loss of the available marketable $(>24 \mathrm{~cm})$ sole escaping through the cod-end mesh. Those escapes were mainly found in the $24-27 \mathrm{~cm}$ length range. If this length range is abundant on certain fishing grounds the losses will exceed the weight percentages found in this study. For the $90 \mathrm{~mm}$ codends, a smaller $87-88 \mathrm{~mm}$ mesh size was measured during the experiments. In the first experiment these cod-ends resulted in a L50 of $22 \mathrm{~cm}$ with $24 \%$ of the marketable sole weight escaping, those escapees were in the $24-29 \mathrm{~cm}$. In the second experiment the cod-end selectivity curve shifted with the $\mathrm{L} 50$ of $26 \mathrm{~cm}$ well above the minimum landing size, resulting in a weight loss of $38 \%$ of the marketable sole weight, with escapees in the $24-33 \mathrm{~cm}$ range. The mechanism behind the difference in $90 \mathrm{~mm}$ cod-ends selectivity between both experiments is unknown but is likely due to the different cod-end used in the second experiment. This shift was not visible in $80 \mathrm{~mm}$ cod-ends for which the same cod-ends have been used.

The morphological characterises of plaice results in both trails in a steep selection curve, with a L50 of $14 \mathrm{~cm}$ in the $80 \mathrm{~mm}$ cod-ends. In both trials majority of the available undersized plaice population was above $14 \mathrm{~cm}$ therefore $87-91 \%$ of the undersized plaice weight was retained by the $80 \mathrm{~mm}$ cod-ends. Using 87-88 mm cod-ends resulted in a $L 50$ of $16 \mathrm{~cm}$ and $87 \%$ cod-end retention, from $20 \mathrm{~cm}$ length a full cod-end retention was found. For the second trial this was and $17 \mathrm{~cm}$ and $62 \%$ cod-end retention for undersized plaice, with a full retention from $24 \mathrm{~cm}$. Although a larger cod-end mesh size mitigate undersize plaice bycatch, the accompanied losses of marketable sole are larger. This visible in the relative shift in selection curve with increasing mesh sizes, the sole curve tends to shift faster towards larger lengths than the plaice curve. This effect of this shift difference is also visible in the ratio of undersized plaice weights per kilo marketable sole, this ratio increases where a shift from 79 $\mathrm{mm}$ to $87 \mathrm{~mm}$ mesh results in larger undersized plaice catches per kilo marketable sole. Assuming the available sole is fully exploited, fishers using $90 \mathrm{~mm}$ cod-ends need to deliver a higher fishing effort to catch their quota. Although less undersized plaice are caught per haul, the increased effort to fully exploit the sole total allowable catch (TAC) will result in higher discard quantities for undersized plaice and an increased bottom impact and $\mathrm{CO} 2$ emissions as more area needs to be covered.

In the pulse trawl fishery a $79 \mathrm{~mm}$ cod-end is not a legal practice, new cod-ends for this $80 \mathrm{~mm}$ fishery are generally $86 \mathrm{~mm}$ and after several hauls the mesh shrinks to 81-82. When an average mesh size of $80 \mathrm{~mm}$ is approaching, the cod-end is replaced by a new $86 \mathrm{~mm}$ cod-end. Considering commercial sole losses $88 \mathrm{~mm}$ cod-ends in this trial, $86 \mathrm{~mm}$ will have substantial losses of the smaller marketable sole. Due to shrinking mesh twine, with a $90 \mathrm{~mm}$ minimum mesh size fishers may have to start with $95 \mathrm{~mm}$ cod-ends, this leads to larger reductions in marketable sole catches. Those substantial losses of legal marketable sole may enhance illegal measures to limit the mesh opening in commercial fisheries. Clearly increasing the minimum mesh sized in this fishery does not solve the bycatch problems, trawl innovations separating sole and the other catch may be the way forward to mitigate bycatch in this fishery.

Observed catch differences in this study for marketable turbot and brill are likely the results of natural variation in the abundancy on the fishing grounds. Both species are morphologically not able to escape from the assessed mesh sizes from the cod-end and are frequently caught in low numbers per haul. Therefore, several large individuals in one trawl could result in differences in catch weights per hour (Annex 8).

In commercial fisheries the cod-ends are circumvented with lifting bags with at least twice the mesh size of the cod-end. The lower part of this lifting bag is protected from bottom contact with small netting panels and dolly ropes. In this study the lifting bags were replaced by cod-end covers. The protecting bags with dolly ropes may reduce cod-end selectivity in a commercial fishery, however this never studied in this fishery.

The results of this study could be used to model a different exploitation pattern with a 90 mm fishery aiming for larger sole could. Short and long term economic consequences of a changing exploitation pattern could give more insights it weather is profitable to change to a larger mesh size on the long term. 


\section{Conclusions and recommendations}

With a mesh size of $79 \mathrm{~mm}$ the L50 for sole is $19 \mathrm{~cm}$ and the selection range is $4.9 \mathrm{~cm}$. With the available sole on the fishing grounds of this pulse trawler this results in a $10 \%$ loss of marketable sole $(>24 \mathrm{~cm}$ ) in the catch. Those losses were detected in the $24-27 \mathrm{~cm}$ length range.

Increasing the mesh size to $87 \mathrm{~mm}$ resulted in a L50 for sole of $22 \mathrm{~cm}$ and a selection range of $4.9 \mathrm{~cm}$ in experiment 1 . In experiment 2 this was $26 \mathrm{~cm}$ with a selection range of $4.9 \mathrm{~cm}$ for the $88 \mathrm{~mm}$ codend. With the available sole on the fishing grounds this resulted in a $24 \%$ and $38 \%$ loss of marketable sole $(>24 \mathrm{~cm})$ in the catch in experiment 1 and 2 , respectively. Those losses were detected in the in the $24-33 \mathrm{~cm}$ length range.

Plaice showed steep selection curve in both experiments with a L50 of $14.4 \mathrm{~cm}$ (SR 2.5) for the 80 $\mathrm{mm}$ cod-ends and $14.1 \mathrm{~cm}$ (SR 2.1) for the $79 \mathrm{~mm}$ cod-ends. In the $87 \mathrm{~mm}$ cod-ends this L50 shifted to $15.6 \mathrm{~cm}$ (SR 2.5) for experiment 1 and $18.7 \mathrm{~cm}$ (SR 2.1) for the $88 \mathrm{~mm}$ cod-ends in experiment 2 .

The ratio of $\mathrm{kg}$ plaice discards per $\mathrm{kg}$ marketable sole was 0.4 in experiment one for $80 \mathrm{~mm}$ cod-ends and increased to 0.5 in a $87 \mathrm{~mm}$ cod-end. For the second experiment this was 2.3 for the $79 \mathrm{~mm}$ and 2.5 for the $88 \mathrm{~mm}$ cod-ends. 


\section{Acknowledgements}

This study was commissioned by VISNED, The Netherlands and partly funded by the European Union, European Maritime and Fisheries Fund (EMFF). The authors would like the following persons and organisations for their contributions to this project. Special thanks Koos and Kees Boersen and crew of the pulse vessel for efforts constructing cod-ends, covers and kites for the trials, changing four codends halfway the trial and collecting all undersized plaice and sole while sorting the catch. Ed de Heer and Wouter van Broekhoven for project management. Teun van Dam and Coöperatie Westvoorn for preparing the cod-ends and covers for the second trial. Floor Quirijns for supporting data collection at sea. Michiel Dammers and Eugene Rurangwa for their assistance in data digitizing and checks, Jurgen Batsleer for project management and Adriaan Rijnsdorp voor reviewing the report. 


\section{References}

Alverson, D. L., Feeberg, M. H., Murawsky, S. A., and Pope, J. A. 1994. A global assessment of fisheries by-catch and discards, FAO, Rome.

Bergman, M. J. N., and van Santbrink, J. W. 2000. Mortality in megafaunal benthic populations caused by trawl fisheries on the Dutch continental shelf in the North Sea in 1994. Ices Journal of Marine Science, 57: 1321-1331.

Borges, L. 2015. The evolution of a discard policy in Europe. Fish and Fisheries, 16: 534-540.

Condie, H., Grant, A., and Catchpole, T. 2013a. Incentivising selective fishing under a policy to ban discards; lessons from European and global fisheries. Marine Policy.

Condie, H. M., Grant, A., and Catchpole, T. L. 2013b. Does banning discards in an otter trawler fishery create incentives for more selective fishing? Fisheries Research, 148: 137-146.

Creutzberg, F., Duineveld, G. C. A., and Van Noort, G. J. 1987. The effect of different number of tickler chains on beam trawl catches. Journal Conseil international Exploration de la Mer, 43: 159-168.

Douglas Bates, Martin Maechler, Ben Bolker, Steve Walker (2015). Fitting Linear Mixed-Effects Models Using Ime4. Journal of Statistical Software, 67(1), 1-48.<doi:10.18637/jss.v067.i01>.

Fonteyne, R., Buglioni, G., Leonori, I., O’Neil F.G., Fryer, R.J., 2007. Laboratory and field trials of OMEGA, a new objective mesh gauge. Fish. Res. 85, 197-201

de Haan, D., Fosseidengen, J. E., Fjelldal, P. G., Burggraaf, D., and Rijnsdorp, A. D. 2016. Pulse trawl fishing: characteristics of the electrical stimulation and the effect on behaviour and injuries of Atlantic cod (Gadus morhua). ICES Journal of Marine Science: Journal du Conseil, 73: 15571569.

Jennings, S., and Kaiser, M. J. 1998. The effects of fishing on marine ecosystems. Advances in Marine Biology, 34: 201-352.

Kaiser, M. J., and Spencer, B. E. 1996. The effects of beam-trawl disturbance on infaunal communities in different habitats. Journal of Animal Ecology, 65: 348-358.

Kelleher, K. 2005. Discards in the world's marine fisheries: an update, Food and Agriculture Organisation, Rome. $131 \mathrm{pp}$.

R Development Core Team. 2004. R: A language and environment for statistical computing. R Foundation for Statistical Computing, Vienna, Austria.

Soetaert, M., Decostere, A., Polet, H., Verschueren, B., and Chiers, K. 2015. Electrotrawling: a promising alternative fishing technique warranting further exploration. Fish and Fisheries, 16: 104-124.

van Beek, F. A. 1998. Discarding in the Dutch beam trawl fishery. ICES CM 1998/, BB:5.

van Marlen, B., Wiegerinck, J. A. M., van Os-Koomen, E., and van Barneveld, E. 2014. Catch comparison of flatfish pulse trawls and a tickler chain beam trawl. Fisheries Research, 151: 5769.

van Stralen, M. R. 2005. De Pulskor. MarinX-rapport 2005.2. . 26 pp.

Wileman, D.A., Ferro, R.S.T., Fonteyne, R., 1996. Manual of methods of measuring the selectivity of towed fishing gears. ICES Coop. Res. Rep. 215, 216 


\section{Justification}

Report C049/18

Project Number: 4311400005

The scientific quality of this report has been peer reviewed by a colleague scientist and a member of the Management Team of Wageningen Marine Research

Approved: $\quad$ Dr. A.D. Rijnsdorp

Senior researcher

Signature:

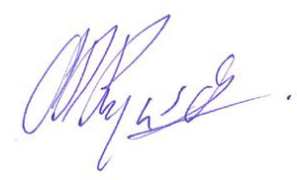

Date:

18 July 2018

Approved:

Dr. ir. T.P. Bult

Director

Signature:

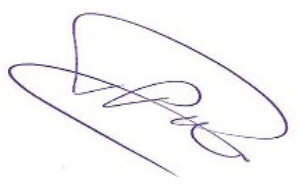

Date:

18 July 2018 


\section{$6 \quad$ Annex sole length distribution and selectivity}

Length frequency per haul, below length frequency als propotion from total observed inividuals of length $\mathrm{x}$.
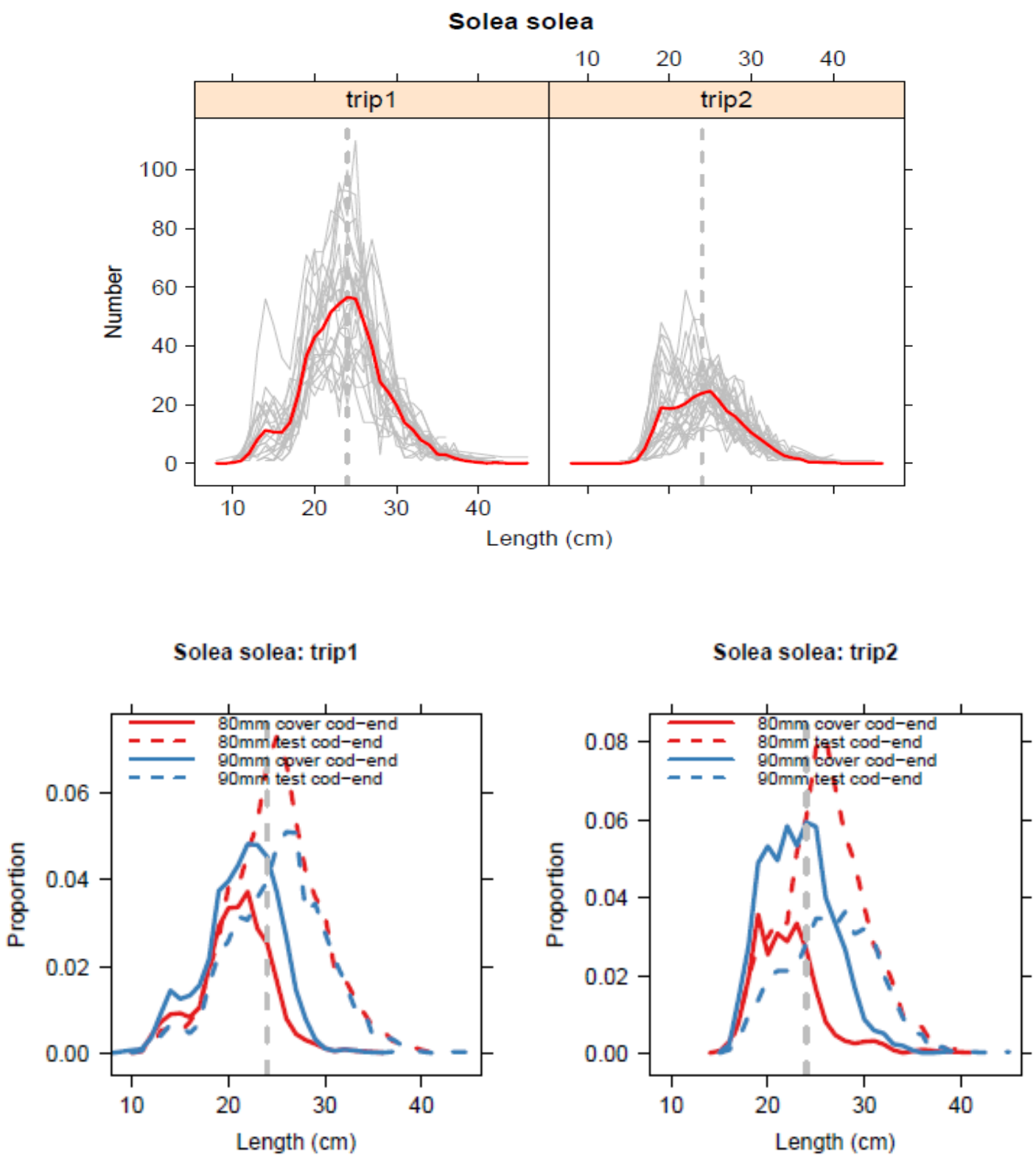

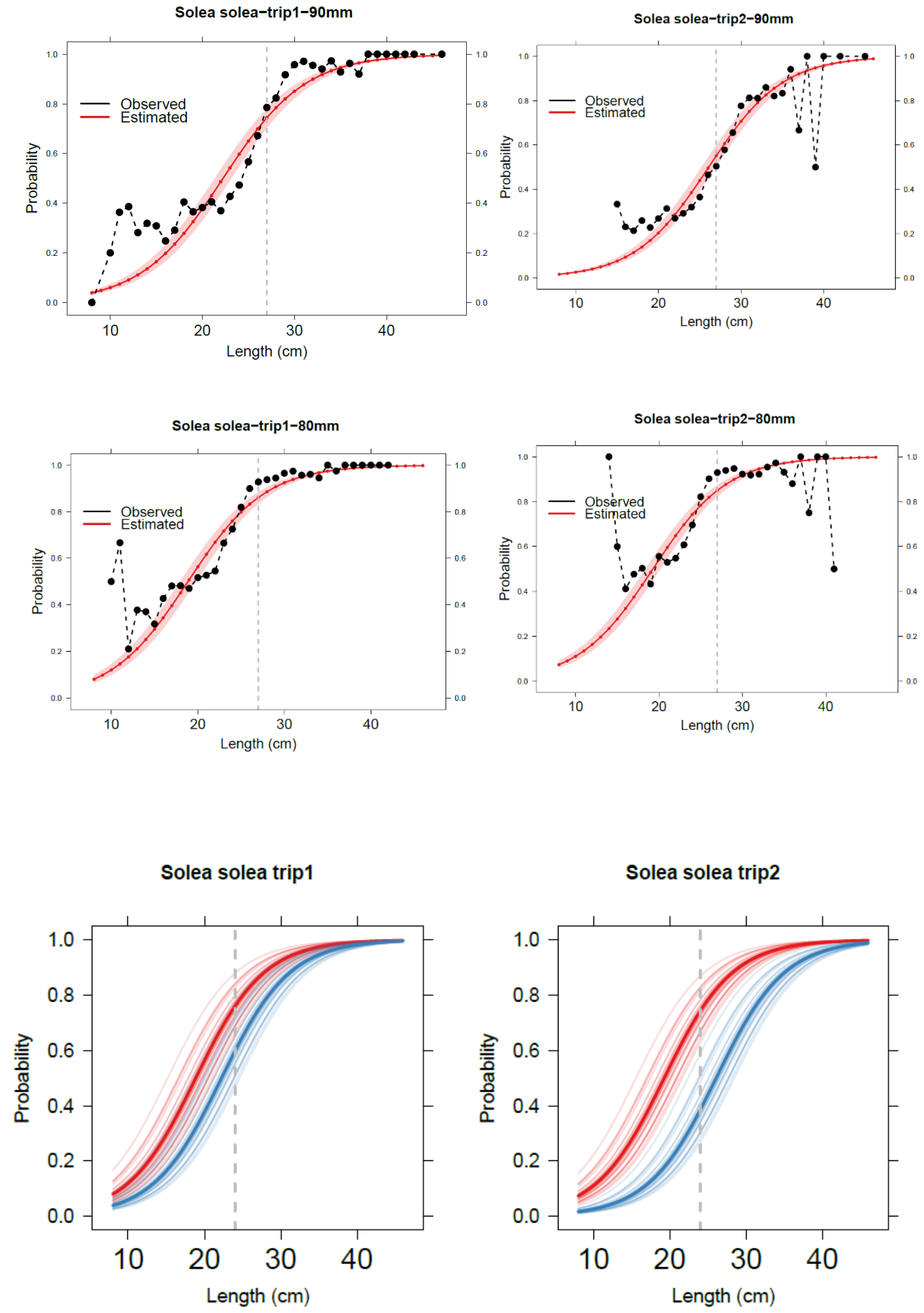


\section{$7 \quad$ Annex plaice length distribution and selectivity}

Selective probabilities and fitted model trough the data poits. Below moddeled selection curves per haul

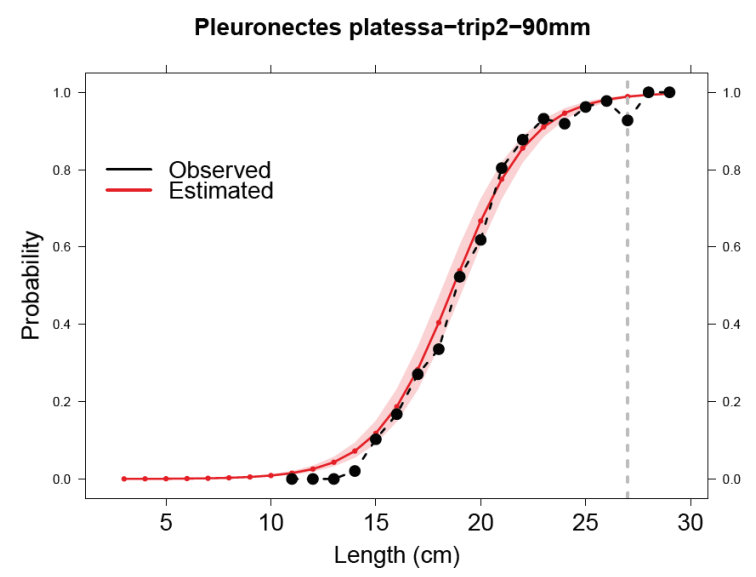

Pleuronectes platessa-trip2-80mm

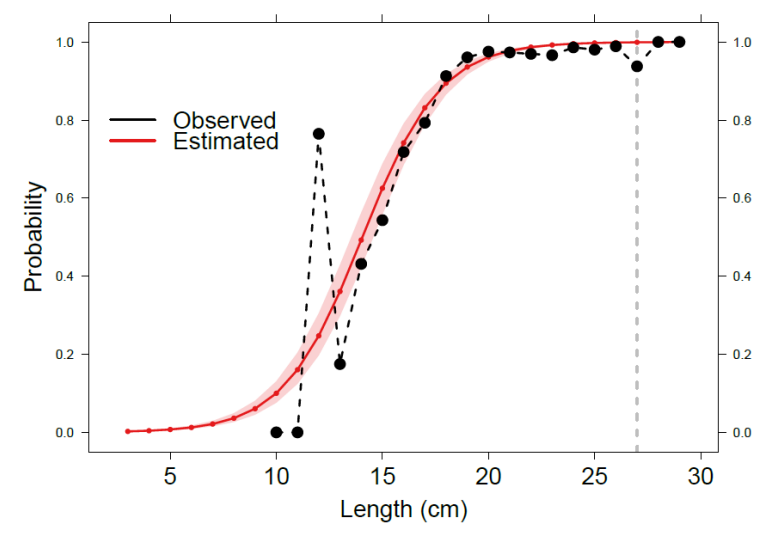

Pleuronectes platessa trip1

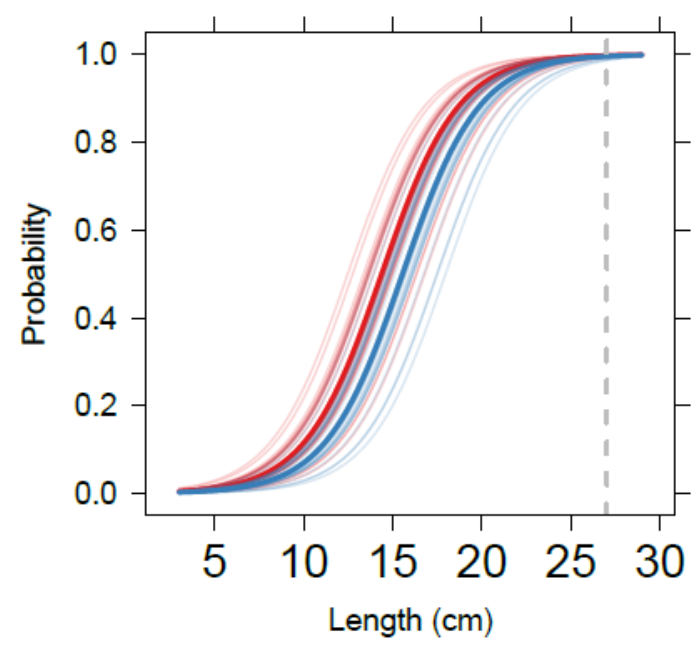

Pleuronectes platessa-trip1-90mm

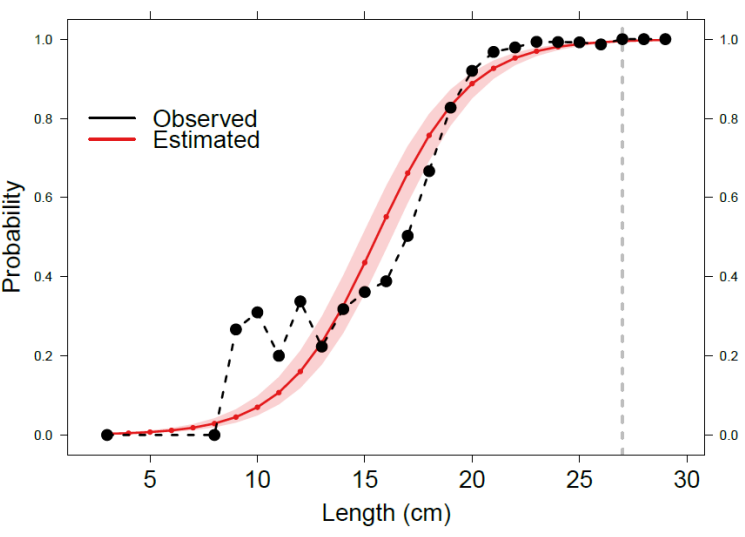

Pleuronectes platessa-trip1-80mm

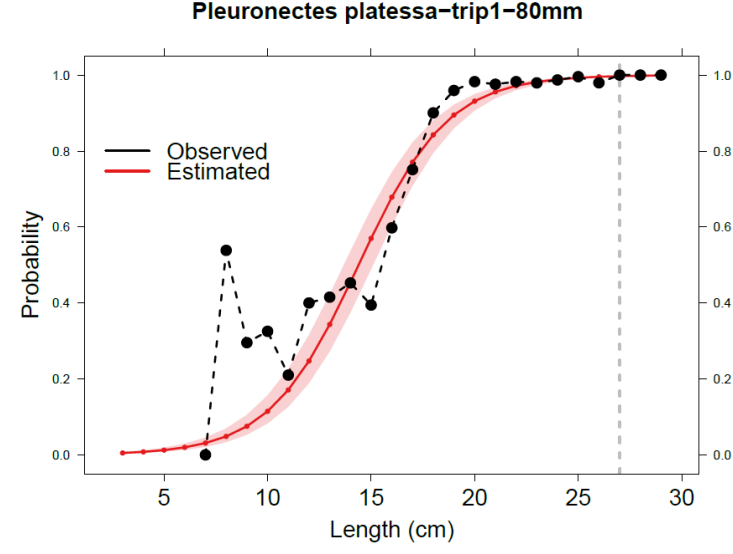

Pleuronectes platessa trip2

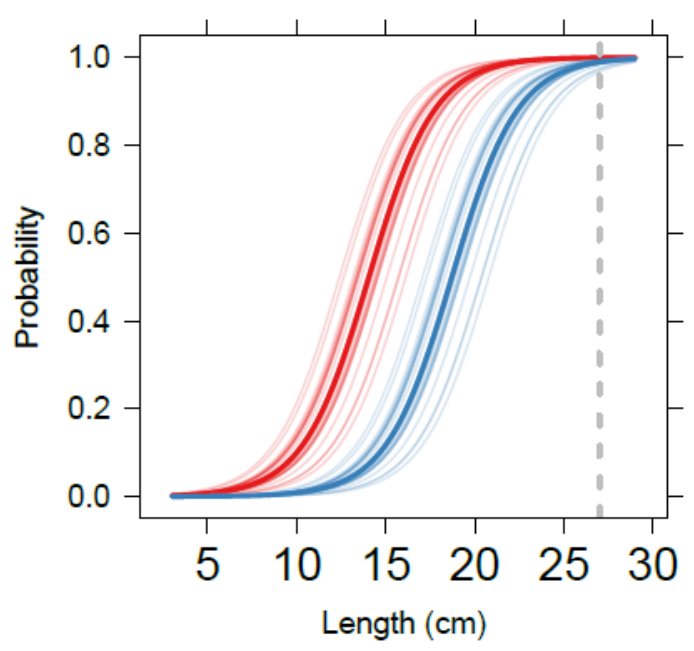

Figure 3: Estimated vs. observed selectivity curve for Solea solea. The observed selectivity is estimated by every $1 \mathrm{~cm}$ length bin. 


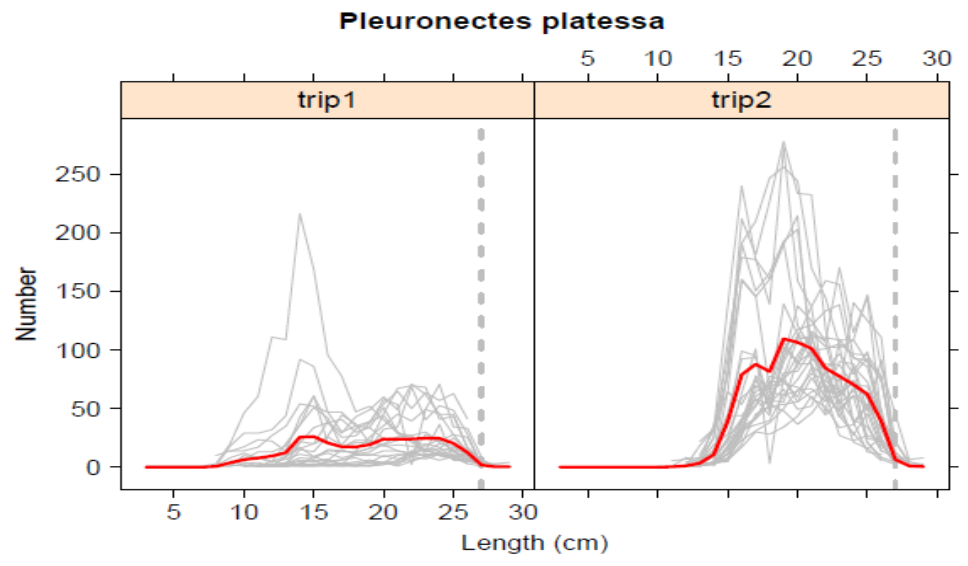

Pleuronectes platessa: trip1

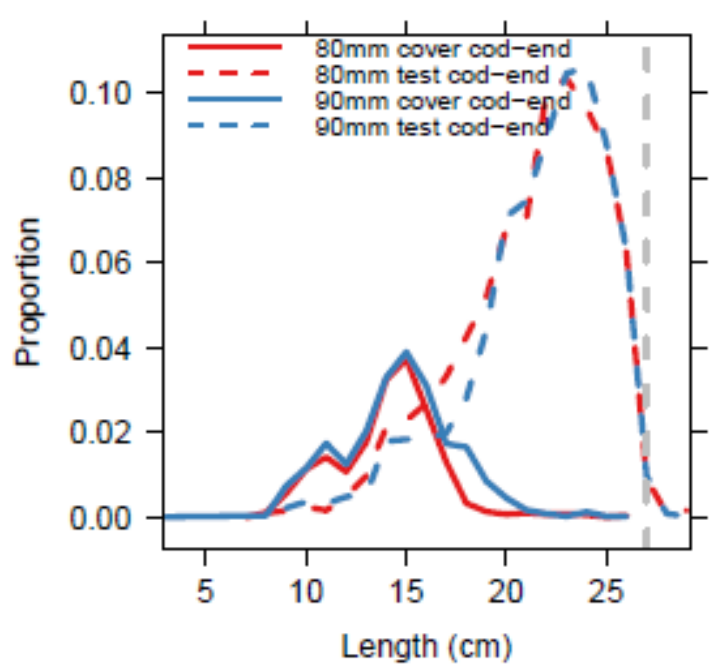

Pleuronectes platessa: trip2

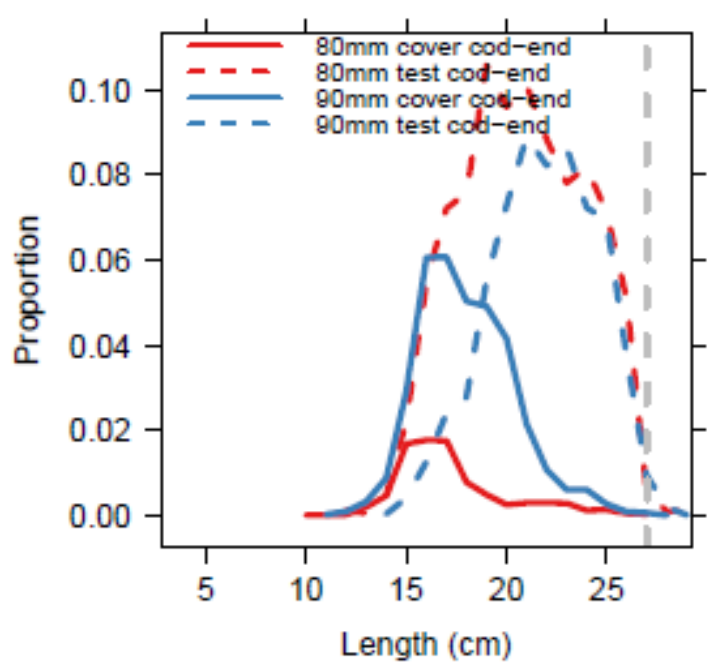


Solea solea

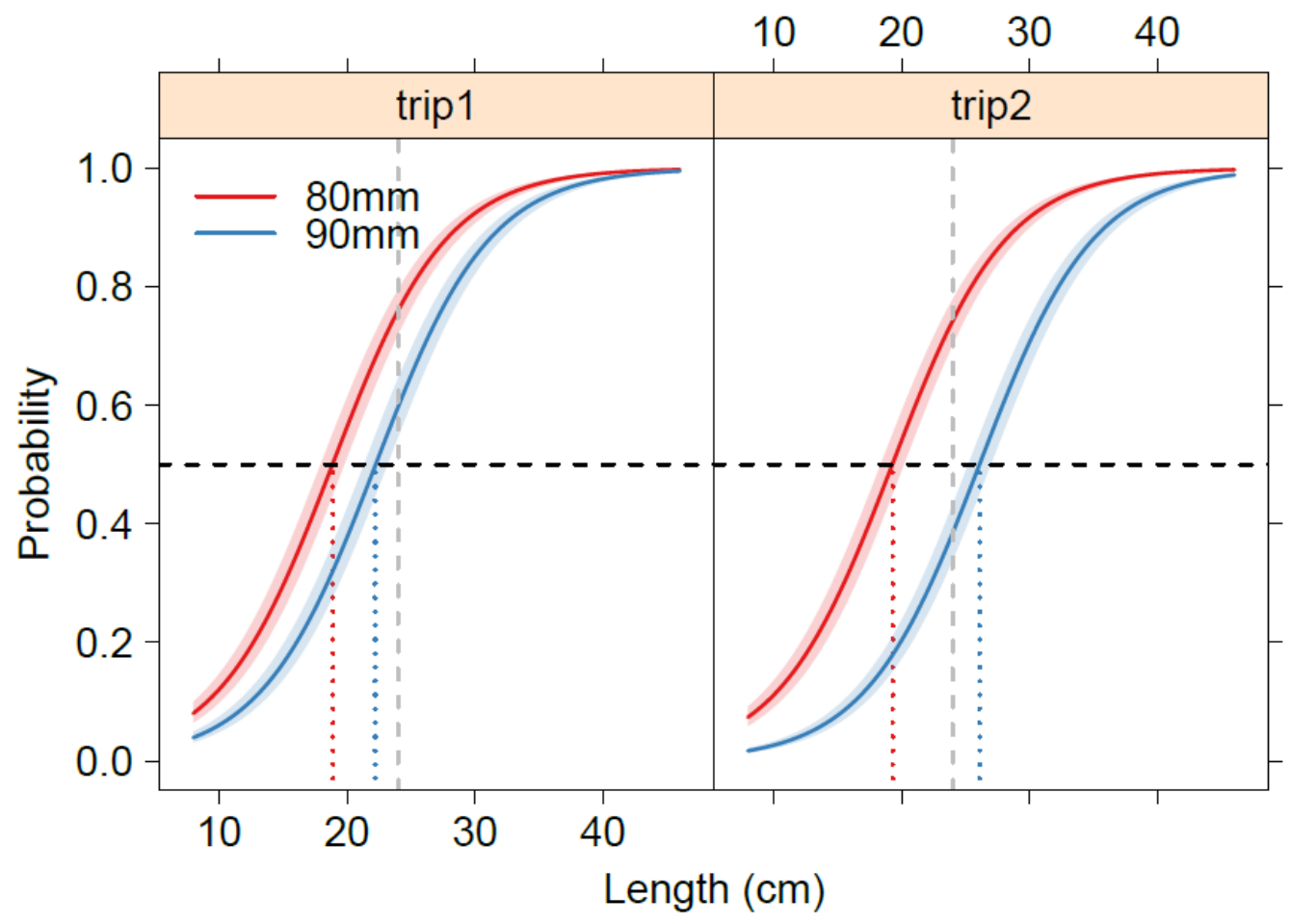

Pleuronectes platessa

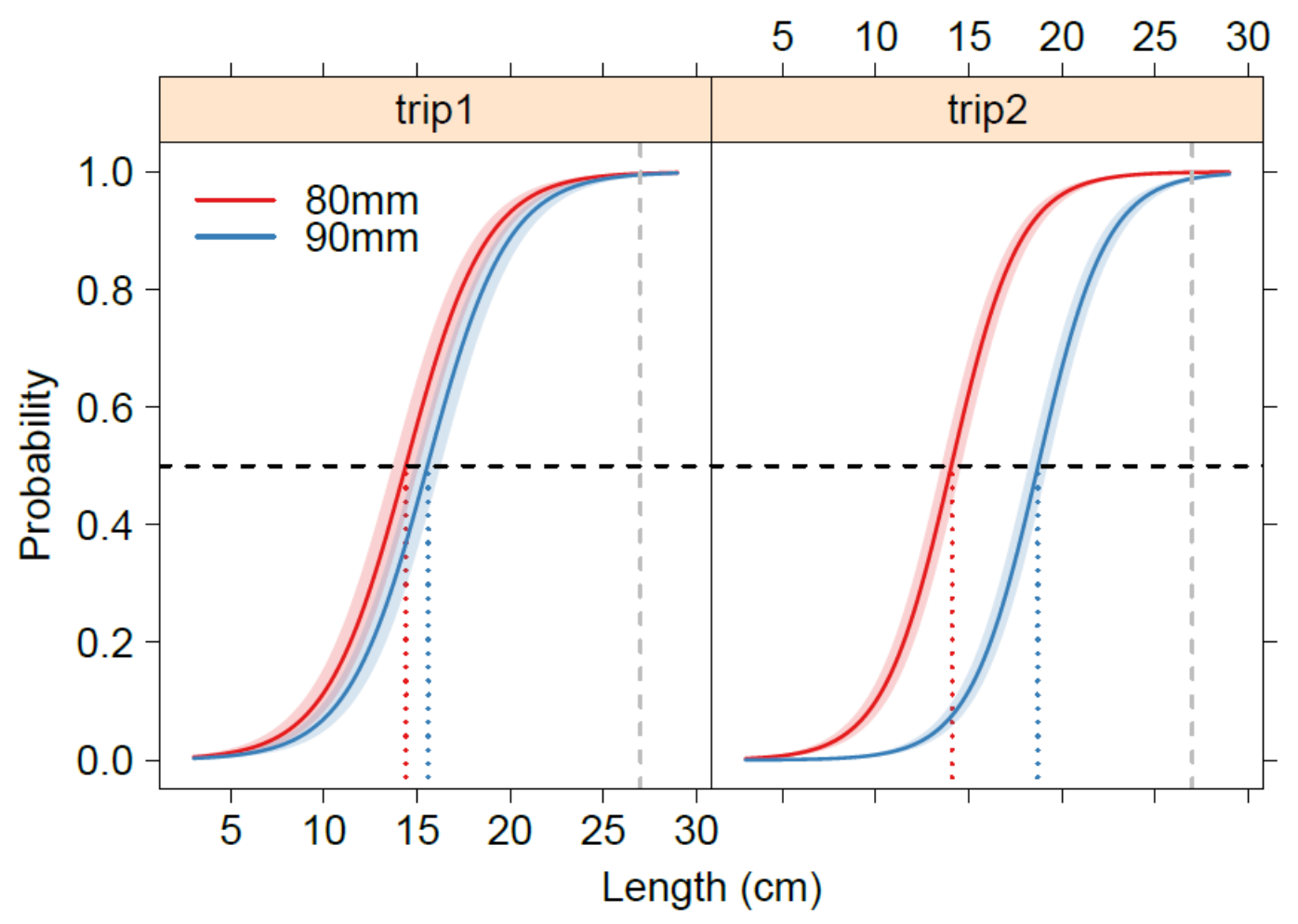




\section{Annex average catch weights per haul for other marketable species}
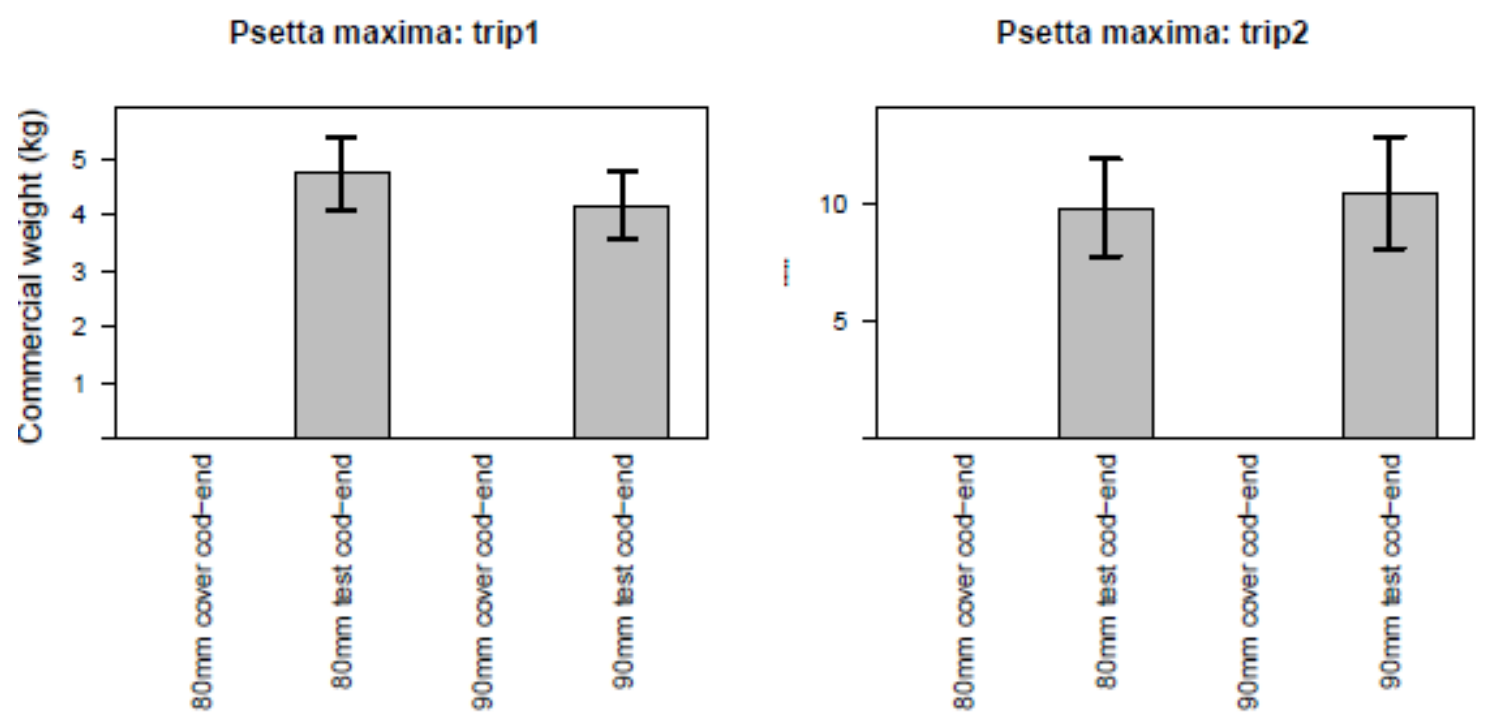

Limanda limanda: trip1

Limanda limanda: trip2
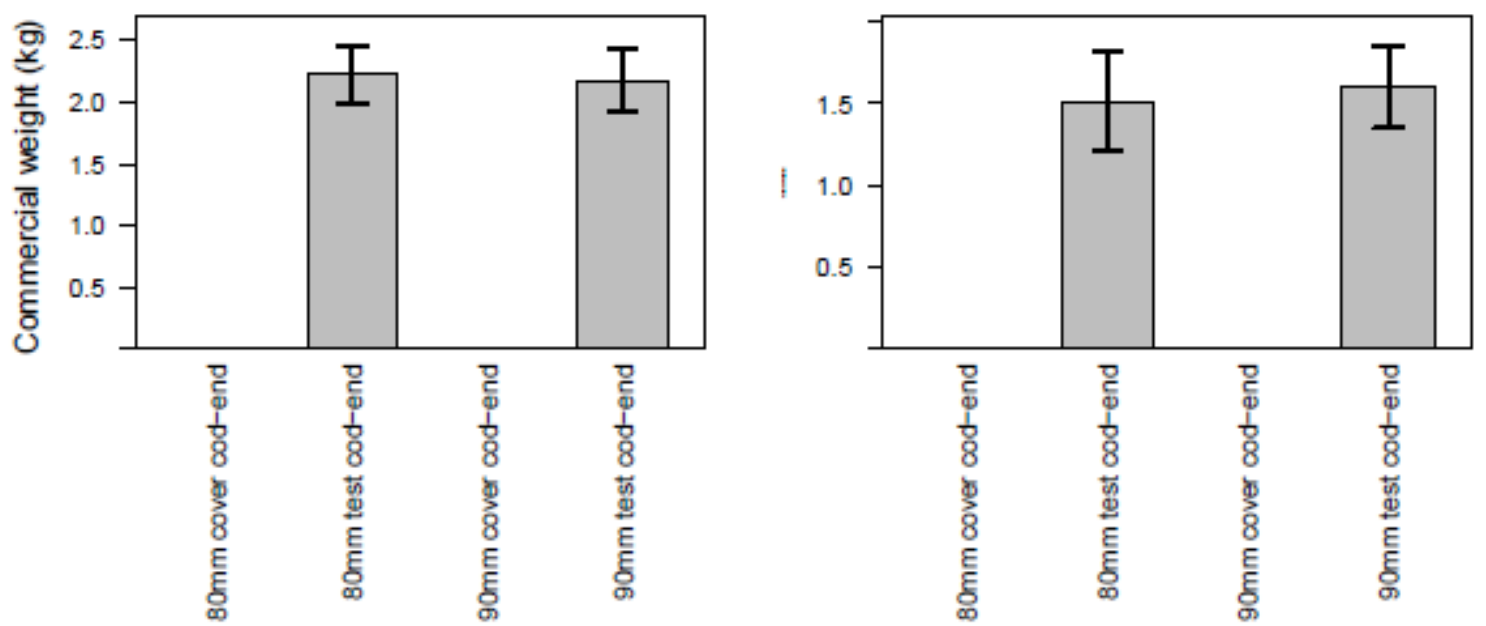

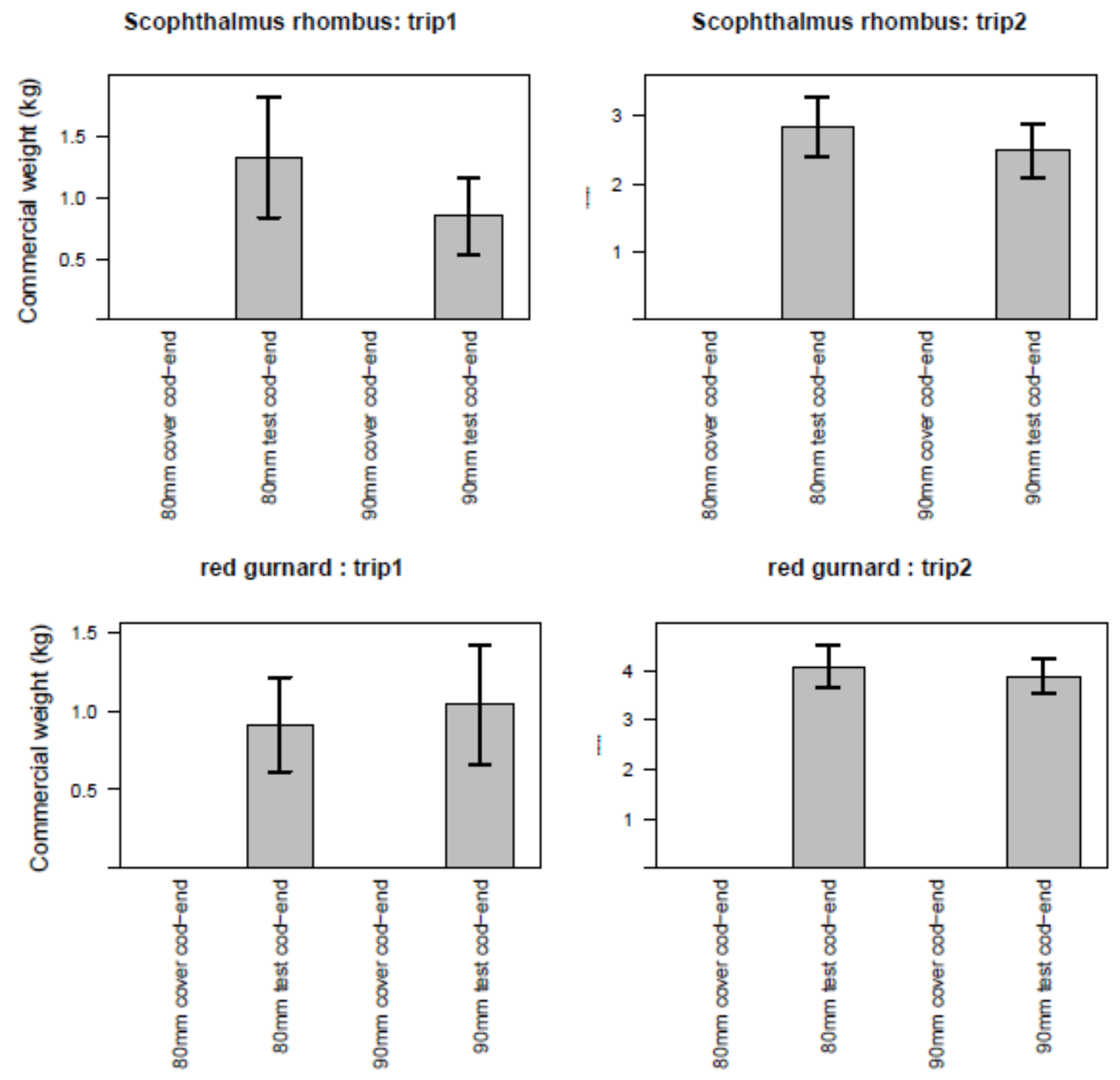
Wageningen Marine Research

$\mathrm{T}+31(0) 317480900$

E: marine-research@wur.nl

www.wur.eu/marine-research

Visitors' address

- Ankerpark 271781 AG Den Helder

- Korringaweg 7, 4401 NT Yerseke

- Haringkade 1, 1976 CP IJmuiden
Wageningen Marine Research is the Netherlands research institute established to provide the scientific support that is essential for developing policies and innovation in respect of the marine environment, fishery activities, aquaculture and the maritime sector.

\section{Wageningen University \& Research:}

is specialised in the domain of healthy food and living environment.

\section{The Wageningen Marine Research vision}

'To explore the potential of marine nature to improve the quality of life'

\section{The Wageningen Marine Research mission}

- To conduct research with the aim of acquiring knowledge and offering advice on the sustainable management and use of marine and coastal areas.

- Wageningen Marine Research is an independent, leading scientific research institute

Wageningen Marine Research is part of the international knowledge organisation Wageningen UR (University \& Research centre). Within Wageningen UR, nine specialised research institutes of the Stichting Wageningen Research Foundation have joined forces with Wageningen University to help answer the most important questions in the domain of healthy food and living environment. 